SANDIA REPORT

SAND98-0051 • UC-520

Unlimited Release

Printed January 1998
RECENED

MAR 20 A98

OSTI

\title{
Technical Safety Requirements for the Annular Core Research Reactor Facility (ACRRF)
}

DISTRIBUTION OF THIS DOCUNENT IS UNLIMTED ph

K. R. Boldt, F. M. Morris, D. G. Talley, F. M. McCrory

Prepared by

Sandia National Laboratories

Albuquerque, New Mexico 87185 and Livermore, California 94550

Sandia is a multiprogram laboratory operated by Sandia Corporation,

a Lockheed Martin Company, for the United States Department of

Energy under Contract DE-AC04-94AL85000.

Approved for public release; further dissemination unlimited.

Sandia National Laboratories

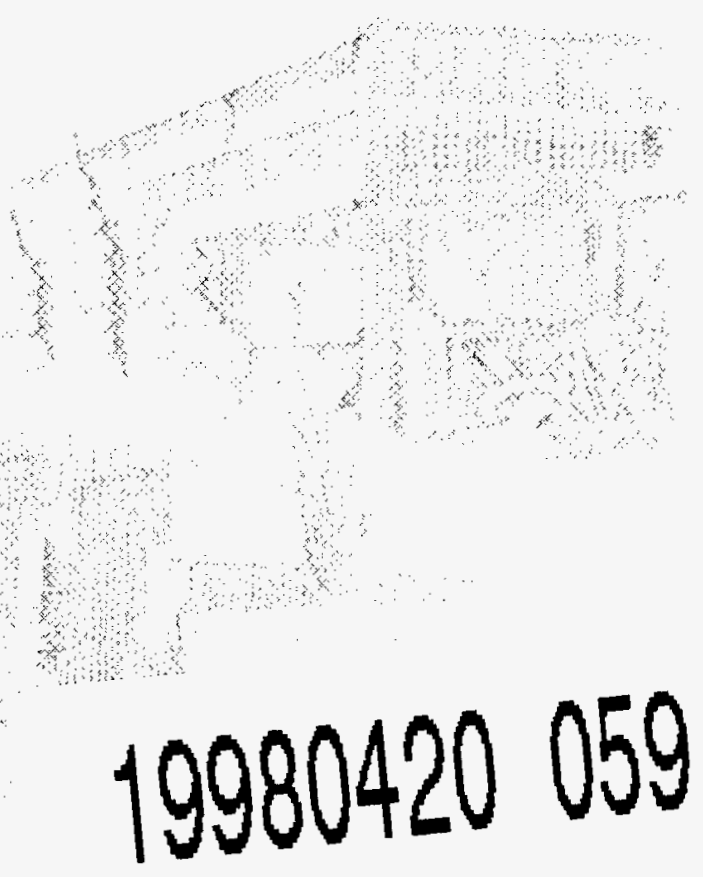


Issued by Sandia National Laboratories, operated for the United States Department of Energy by Sandia Corporation.

NOTICE: This report was prepared as an account of work sponsored by an agency of the United States Government. Neither the United States Government nor any agency thereof, nor any of their employees, nor any of their contractors, subcontractors, or their employees, makes any warranty, express or implied, or assumes any legal liability or responsibility for the accuracy, completeness, or usefulness of any information, apparatus, product, or process disclosed, or represents that its use would not infringe privately owned rights. Reference herein to any specific commercial product, process, or service by trade name, trademark, manufacturer, or otherwise, does not necessarily constitute or imply its endorsement, recommendation, or favoring by the United States Government, any agency thereof, or any of their contractors or subcontractors. The views and opinions expressed herein do not necessarily state or reflect those of the United States Government, any agency thereof, or any of their contractors.

Printed in the United States of America. This report has been reproduced directly from the best available copy.

Available to DOE and DOE contractors from Office of Scientific and Technical Information P.O. Box 62

Oak Ridge, TN 37831

Prices available from (615) 576-8401, FTS 626-8401

Available to the public from

National Technical Information Service

U.S. Department of Commerce

5285 Port Royal Rd

Springfield, VA 22161

NTIS price codes

Printed copy: A03

Microfiche copy: A01

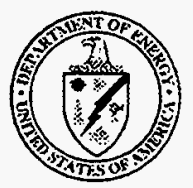


SAND 98-0051

Unlimited Release

Printed January 1998

\title{
TECHNICAL SAFETY REQUIREMENTS FOR THE ANNULAR CORE RESEARCH REACTOR FACILITY (ACRRF)
}

\author{
K. R. Boldt, F. M. Morris, D. G. Talley, F. M. McCrory \\ Nuclear Reactor Facilities Department \\ Sandia National Laboratories, Albuquerque \\ P.O. Box 5800 \\ Albuquerque, New Mexico 87185-1142 \\ January 1998 \\ Approved By:

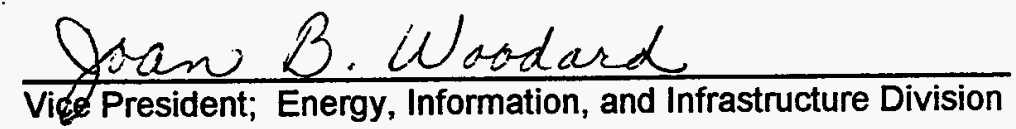

\begin{abstract}
The Technical Safety Requirements (TSR) document is prepared and issued in compliance with DOE Order 5480.22, Technical Safety Requirements. The bases for the TSR are established in the ACRRF Safety Analysis Report issued in compliance with DOE Order 5480.23, Nuclear Safety Analysis Reports. The TSR identifies the operational conditions, boundaries, and administrative controls for the safe operation of the facility.
\end{abstract}


(This Page Intentionally Left Blank) 


\section{CONTENTS}

Section Title Page

INTRODUCTION

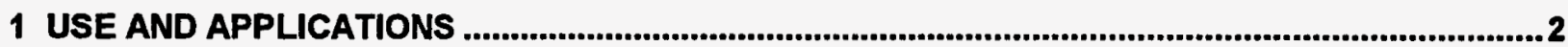

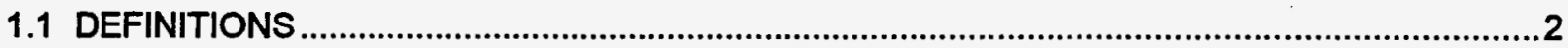

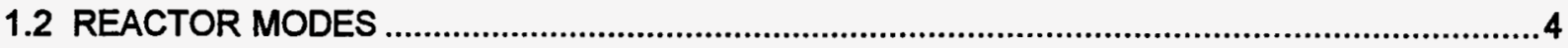

1.2.1 Operating Modes:

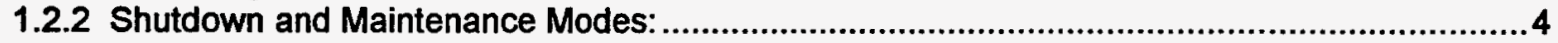

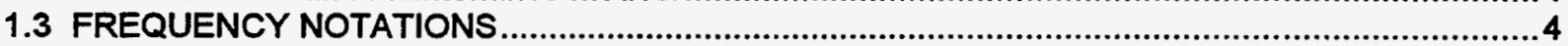

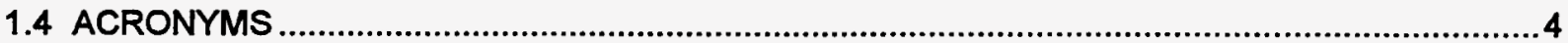

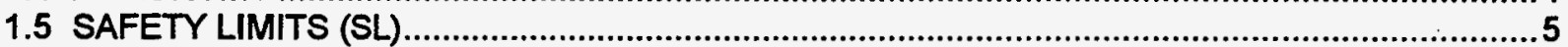

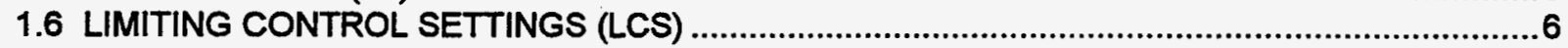

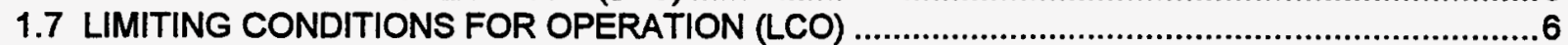

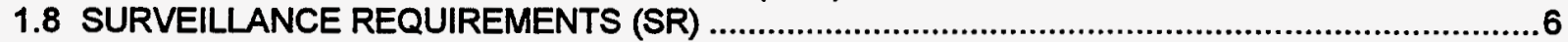

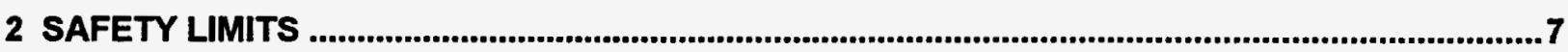

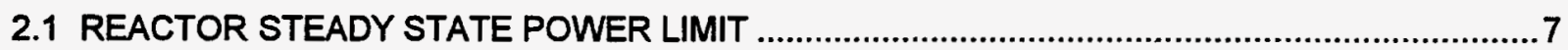

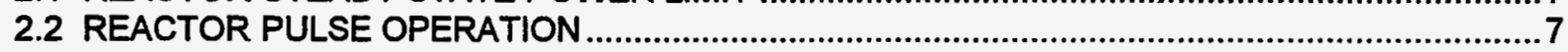

3/4 OPERATIONAL LIMITS AND SURVEILLANCE REQUIREMENTS

3.0 LIMITING CONDITIONS FOR OPERATION (LCO) GENERAL APPLICATION...........................8

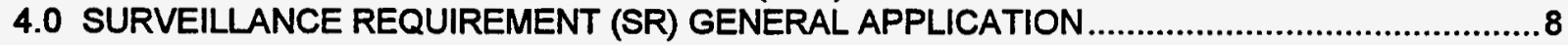

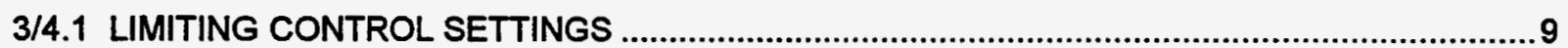

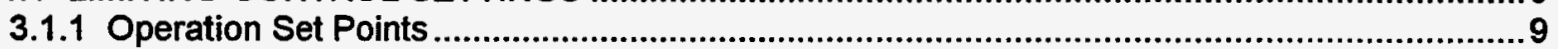

4.1.1 Operations Set Point Surveillance Requirements .......................................................... 9

3/4.2 LIMITING CONDITIONS FOR OPERATION (LCO) ........................................................ 10

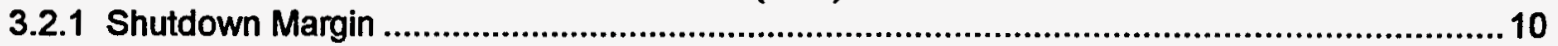

4.2.1 Shutdown Margin Surveillance Requirements: ..........................................................10

3.2.2 Excess Reactivity and Reactivity Insertion Rate ..........................................................11

4.2.2 Excess Reactivity and Reactivity Insertion Rate Surveillance Requirements:......................11

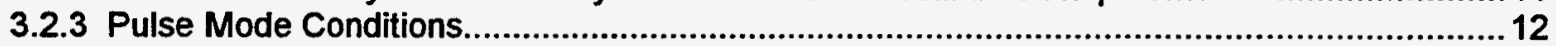

4.2.3 Pulse Mode Conditions Surveillance Requirements:....................................................... 13

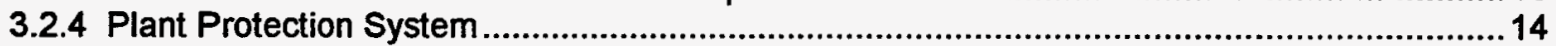

4.2.4 Plant Protection System Surveillance Requirements: ..................................................... 15

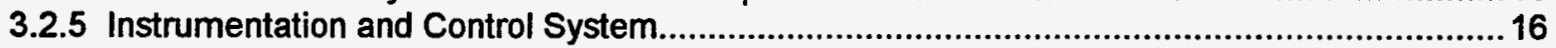

4.2.5 Instrumentation and Control System Surveillance Requirements:.....................................17

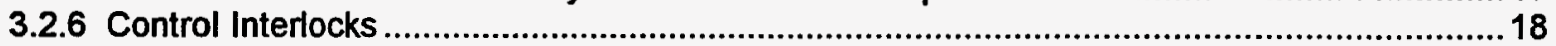

4.2.6 Control Interlocks Surveillance Requirements: ............................................................ 19

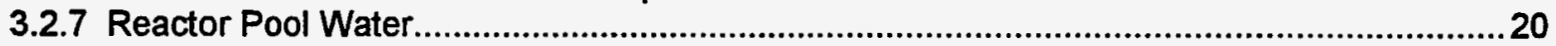

4.2.7 Reactor Pool Water Surveillance Requirements:.........................................................20

3.2.8 Reactor Room Exhaust (Confinement) Systems.........................................................21

4.2.8 Reactor Room Exhaust (Confinement) Systems Surveillance Requirements:......................21

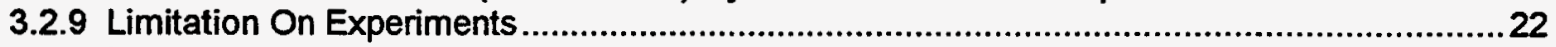

4.2.9 Limitation On Experiments Surveillance Requirements: ............................................22

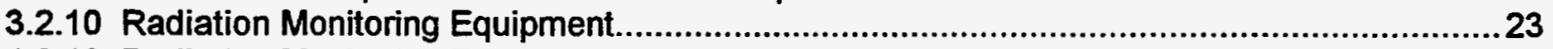

4.2.10 Radiation Monitoring Equipment Surveillance Requirements:.....................................23 
Section Title $\quad$ Page

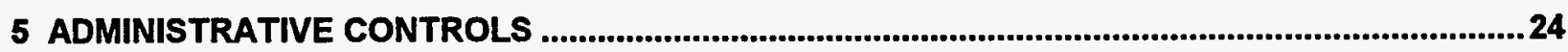

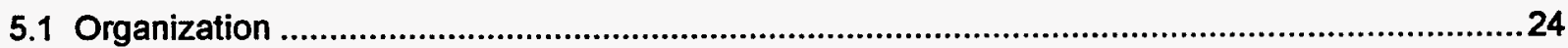

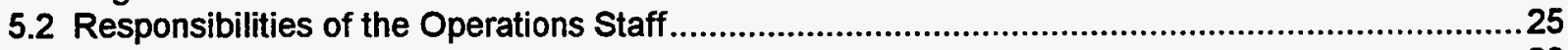

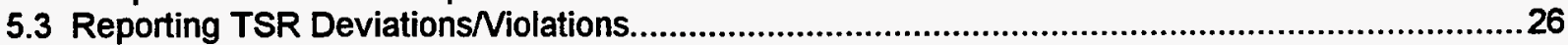

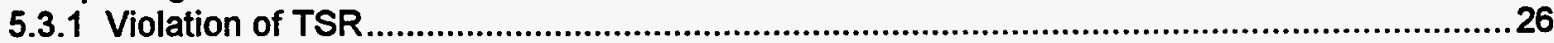

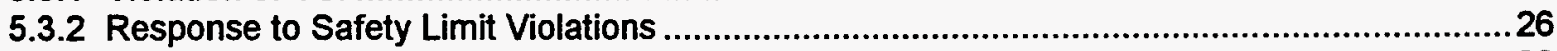

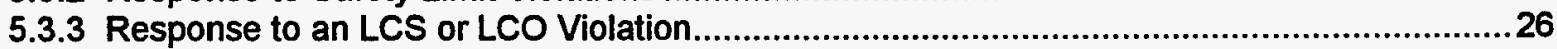

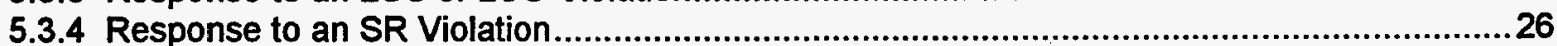

5.3.5 Response to an Administrative Controls (AC) Violation ...................................................26

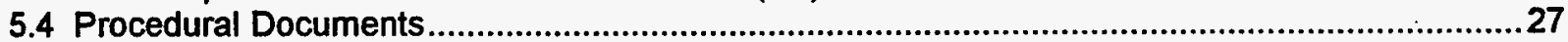

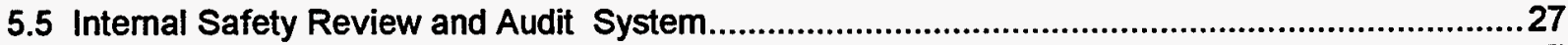

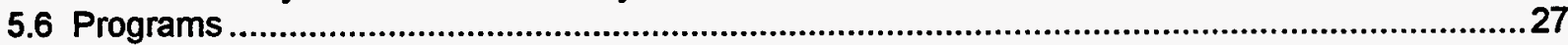

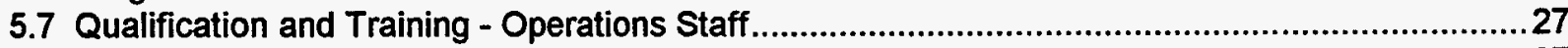

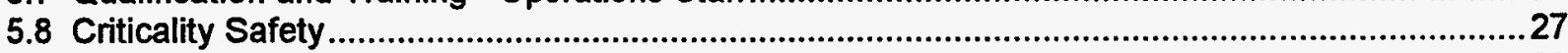

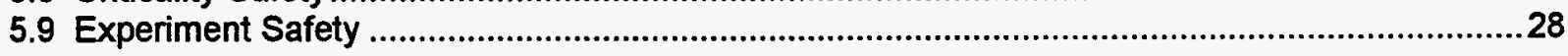

\section{LIST OF FIGURES}

Figure

Number

Title

Page

5-1

Administrative Line of Responsibility 


\title{
TECHNICAL SAFETY REQUIREMENTS
}

for the

\author{
ANNULAR CORE RESEARCH REACTOR FACILITY (ACRRF)
}

\section{INTRODUCTION}

This document provides the Technical Safety Requirements (TSR) for the Annular Core Research Reactor Facility (ACRRF). The TSR is a compilation of requirements that define the conditions, the safe boundaries, and the administrative controls necessary to ensure the safe operation of a nuclear facility and to reduce the potential risk to the public and facility workers from uncontrolled releases of radioactive or other hazardous materials. These requirements constitute an agreement between DOE and Sandia National Laboratories management regarding the safe operation of the Annular Core Research Reactor (ACRR).

This document conforms to the outline provided in Attachment 1 of DOE Order 5480.22 and the DOE Defense Programs Document of Example Technical Safety Requirements. Section 1, "Use and Application" contains basic information and instructions for using and applying the TSR. Section 2, "Safety Limits" provides the limits on important process variables. Section 3/4, "Operational Limits and Surveillance Requirements" contains the Limiting Control Settings and the Limiting Conditions for Operation, as well as Mode Applicability, Action Statements, and Surveillance Requirements for each requirement. Section 5, "Administrative Controls" imposes administrative requirements necessary to control operation of facility such that the TSR is satisfied. Appendix A, "Bases for the Technical Safety Requirements," provides rationale for the selection of the Safety Limits, Operating Limits, and associated Mode Applicabilities, Action Statements, and Surveillance Requirements. 


\subsection{DEFINITIONS}

Defined terms in this list appear in upper-case throughout this document.

\begin{tabular}{|c|c|}
\hline CHANNEL & $\begin{array}{l}\text { The combination of sensor, line, amplifier, and output devices which are } \\
\text { connected for the purpose of measuring the value of a parameter. }\end{array}$ \\
\hline CALIBRATE & $\begin{array}{l}\text { An adjustment of the channel such that its output corresponds with } \\
\text { acceptable accuracy to known values of the parameter which the channel } \\
\text { measures. }\end{array}$ \\
\hline CHANNEL CHECK & $\begin{array}{l}\text { A qualitative verification of acceptable performance by observation of } \\
\text { channel behavior, or by comparison of the channel with other independent } \\
\text { channels or systems measuring the same variable. }\end{array}$ \\
\hline CHANNEL TEST & $\begin{array}{l}\text { The introduction of a signal into the channel for verification that it is } \\
\text { operable. }\end{array}$ \\
\hline COLD CRITICAL & $\begin{array}{l}\text { Cold critical is that reactor condition when the reactor is at delayed critical } \\
\text { and the power level is less than or equal to } 1 \% \text { of full power. }\end{array}$ \\
\hline $\begin{array}{l}\text { CORE } \\
\text { CONFIGURATION } \\
\text { CHANGE }\end{array}$ & $\begin{array}{l}\text { A change in the number, type, or arrangement of fuel elements, reflector } \\
\text { elements, or regulating rods occupying the core grid or external cavities } \\
\text { adjacent to the core. }\end{array}$ \\
\hline $\begin{array}{l}\text { DESIGN BASIS } \\
\text { ACCIDENTS (DBA) }\end{array}$ & $\begin{array}{l}\text { Accidents postulated for the purpose of establishing functional } \\
\text { requirements for safety structures, systems, and components. }\end{array}$ \\
\hline $\begin{array}{l}\text { DOUBLE } \\
\text { CONTAINMENT }\end{array}$ & $\begin{array}{l}\text { Two full enclosures such that the container which encloses the materials is } \\
\text { contained within the second container }\end{array}$ \\
\hline $\begin{array}{l}\text { DYNAMIC } \\
\text { REACTIVITY } \\
\text { WORTH }\end{array}$ & $\begin{array}{l}\text { Reactivity worth determined by measurement of the reactor period before } \\
\text { temperature feedback effects reactivity. }\end{array}$ \\
\hline EQUILIBRIUM & $\begin{array}{l}\text { A reactor state characterized by steady fuel temperatures and minimal } \\
\text { regulating rod movement to maintain desired power level. }\end{array}$ \\
\hline $\begin{array}{l}\text { EXCESS } \\
\text { REACTIVITY }\end{array}$ & $\begin{array}{l}\text { The amount of reactivity available, in excess of the cold critical condition, } \\
\text { which would exist if all regulating rods were moved to the maximum } \\
\text { reactive condition. }\end{array}$ \\
\hline EXPERIMENT & $\begin{array}{l}\text { 1. Any apparatus, device or material placed in the reactor core region, in } \\
\text { an experiment facility, or in line with a beam of radiation from the reactor. } \\
\text { 2. Any operation designed to investigate non-routine reactor } \\
\text { characteristics. }\end{array}$ \\
\hline $\begin{array}{l}\text { HAZARDOUS } \\
\text { MATERIALS }\end{array}$ & $\begin{array}{l}\text { Those materials which can cause localized damage or personnel injury as } \\
\text { a result of decomposition from radiation, chemical action, or corrosion. } \\
\text { Fission products and isotopes of uranium and plutonium are not included in } \\
\text { this definition since restrictions are separately identified for these } \\
\text { materials. }\end{array}$ \\
\hline IMMEDIATELY & $\begin{array}{l}\text { Prior to performance of any other action (except evaluation) but not to } \\
\text { exceed } 5 \text { minutes. }\end{array}$ \\
\hline $\begin{array}{l}\text { MOVEABLE } \\
\text { EXPERIMENT }\end{array}$ & $\begin{array}{l}\text { An experiment designed to move before or during a reactor operation, in a } \\
\text { manner that affects the experiment reactivity worth seen by the reactor. }\end{array}$ \\
\hline
\end{tabular}




\begin{tabular}{|c|c|}
\hline $\begin{array}{l}\text { OPERABLE (or } \\
\text { OPERABILITY) }\end{array}$ & Component or system is capable of performing its intended function \\
\hline OPERATING & Component or system is performing its intended function. \\
\hline $\begin{array}{l}\text { PLANT } \\
\text { PROTECTION } \\
\text { SYSTEM (PPS) }\end{array}$ & $\begin{array}{l}\text { The protective instrument system intended to sense the occurrence of } \\
\text { accident conditions and to scram the reactor. }\end{array}$ \\
\hline $\begin{array}{l}\text { POWER } \\
\text { DETERMINATION }\end{array}$ & $\begin{array}{l}\text { Combination of experimental and calculational techniques to determine the } \\
\text { peak fuel element location, power per peak fuel element and/or total } \\
\text { reactor power. }\end{array}$ \\
\hline $\begin{array}{l}\text { REACTOR } \\
\text { OPERATOR }\end{array}$ & $\begin{array}{l}\text { An individual that has satisfactorily completed the Sandia Reactor } \\
\text { Operator certification training program. }\end{array}$ \\
\hline $\begin{array}{l}\text { REACTOR } \\
\text { SUPERVISOR }\end{array}$ & $\begin{array}{l}\text { An individual that has satisfactorily completed the Sandia Reactor } \\
\text { Supervisor certification training program. }\end{array}$ \\
\hline $\begin{array}{l}\text { REGULATING } \\
\text { RODS }\end{array}$ & $\begin{array}{l}\text { An assembly of mechanical, electrical, pneumatic, poison, fuel, and } \\
\text { associated hardware designed for the specific purpose of controlling the } \\
\text { reactivity state of the reactor. As applied to the ACRR, these assemblies } \\
\text { are the control rods, transient rods, and safety rods. }\end{array}$ \\
\hline ROD DROP TIME & $\begin{array}{l}\text { That time measured from loss of magnet/solenoid currents in the PPS to } \\
\text { the time that regulating rods are completely inserted with full negative } \\
\text { reactivity. }\end{array}$ \\
\hline SCRAM & $\begin{array}{l}\text { Removal of magnet current by action of a Safety Channel in the Plant } \\
\text { Protection System }\end{array}$ \\
\hline $\begin{array}{l}\text { SECURED } \\
\text { EXPERIMENT }\end{array}$ & $\begin{array}{l}\text { An experiment held firmly in place by a mechanical device or by virtue of } \\
\text { its weight, which can be shown to provide an acceptable level of } \\
\text { confidence for preventing movement of the experiment, relative to the } \\
\text { core, during reactor operation. Secured experiments may contain rotating } \\
\text { devices subject to the exclusion noted for Moveable Experiment. }\end{array}$ \\
\hline $\begin{array}{l}\text { SHALL, SHOULD } \\
\text { AND MAY }\end{array}$ & $\begin{array}{l}\text { The word "shall" is used to denote a requirement; the word "should" to } \\
\text { denote a recommendation; and the word "may" to denote permission, } \\
\text { neither a requirement nor a recommendation. }\end{array}$ \\
\hline $\begin{array}{l}\text { SHUTDOWN } \\
\text { MARGIN }\end{array}$ & $\begin{array}{l}\text { The reactivity necessary to provide confidence that the reactor can be } \\
\text { made subcritical by means of the control and safety systems, starting from } \\
\text { any permissible operating condition, and reactor will remain subcritical } \\
\text { without further operator action. The shutdown margin refers to the cold } \\
\text { critical condition with the highest worth regulating -rod fully withdrawn and } \\
\text { any positive worth experiment in its most reactive state. }\end{array}$ \\
\hline $\begin{array}{l}\text { SINGLE } \\
\text { CONTAINMENT }\end{array}$ & $\begin{array}{l}\text { A full enclosure which limits to within acceptable levels the release of the } \\
\text { materials and any energy that can be generated by the enclosed material. }\end{array}$ \\
\hline
\end{tabular}




\subsection{REACTOR MODES}

\subsubsection{Operating Modes:}

STEADY STATE MODE - The Mode switch is in the Steady State position and power is supplied to the regulating rod magnets and the pneumatic or high speed movement of the Transient Rods is prohibited by system interlocks. The AUTO MODE is a subset of the STEADY STATE MODE where changes in the power level may be controlled by a computer.

PULSE MODE - The Mode switch is in the PULSE position, power is supplied to the regulating rod magnets, and reactor operation is characterized by a self terminating power pulse initiated by pneumatic withdrawal of transient rods and the resultant rapid reactivity input PULSE REDUCED TAIL MODE is a subset of the PULSE MODE and differs only in the termination of the pulse. For a reduced tail pulse, all rods drop into the core at the completion of the pulse sequence as opposed to the termination in the PULSE MODE in which only the Transient Rods and the Safety Rods drop into the core. In PULSE MODE, percent power trips are disabled and manual withdrawal of the Control Rods is prohibited.

TRANSIENT ROD WITHDRAWAL (TRW) MODE - A subset of PULSE MODE. The reactor power is controlled by positioning the transient rods electromechanically using either closed or open loop control to achieve a tailored power trace. In TRW MODE, percent power trips are disabled and manual withdrawal of the Control Rods is prohibited.

\subsubsection{Shutdown and Maintenance Modes:}

SHUTDOWN MODE - The operational condition of the reactor characterized by magnet power removed from all regulating rods.

MAINTENANCE - A subcritical reactor mode in which regulating rods or fuel elements may be raised or removed for maintenance activities or testing.

\subsection{FREQUENCY NOTATIONS}

$\begin{array}{ll}\text { NOTATION } & \text { FREQUENCY } \\ { } } & \text { Once per operating day } \\ \text { STARTUP } & \text { Prior to the first reactor operation of the day } \\ \text { ANNUALLY } & \text { Once per calendar year, interval not to exceed } 15 \text { months }\end{array}$

\subsection{ACRONYMS}

The acronyms used in this document are listed below:
AC - Administrative Controls
ACRR - Annular Core Research Reactor
ACRRC - ACRR Safety Committee
ACRRF - Annular Core Research Reactor Facility
CAM - Continuous Air Monitor
DBA - Design Basis Accident
DOE - Department of Energy 


\begin{tabular}{|c|c|}
\hline ES\&H & - Environmental Safety and Health \\
\hline ESSSC & - Engineered Safety Structures, Systems, and Components \\
\hline HEPA & - High Efficiency Particulate Air \\
\hline LCO & - Limiting Condition for Operation \\
\hline LCS & - Limiting Control Settings \\
\hline MCHFR & - Minimum Critical Heat Flux Ratio \\
\hline NV & - PPS Flux Channel measuring peak pulse power \\
\hline NVT & - PPS Fluence Channel measuring total pulse energy \\
\hline PPS & - Plant Protection System \\
\hline RAM & - Radiation Area Monitor \\
\hline SIRAS & - Sandia Internal Review and Appraisal System \\
\hline SL & - Safety Limit \\
\hline SR & - Surveillance Requirement \\
\hline SRSC & - Sandia Reactor Safety Committee \\
\hline $\begin{array}{l}\text { TRW } \\
\text { TSR }\end{array}$ & $\begin{array}{l}\text { - Transient Rod Withdrawal } \\
\text { - Technical Safety Requirements }\end{array}$ \\
\hline $\mathrm{UO}_{2}-\mathrm{BeO}$ & - Uranium Dioxide-Beryllium Oxide fuel material, 21 w/o $\mathrm{UO}_{2}, 35 \%$ enriched \\
\hline
\end{tabular}

The following engineering units are abbreviated in this document:

$\begin{array}{ll}\$ & \text { - Dollar of Reactivity } \\ { }^{\circ} \mathrm{C} & \text { - Degrees Centigrade } \\ \mathrm{cm} & \text { - Centimeters } \\ \mathrm{DPM} & \text { - Decades per Minute } \\ \text { keV } & \text { - Kilo-Electron Volts } \\ \text { KOhm-cm } & \text { - Kilo-Ohm - Centimeters } \\ \text { kW } & \text { - Kilowatts } \\ \text { MJ } & \text { - Megajoules } \\ \text { MW } & \text { - Megawatts } \\ \mathrm{nvt} & \text { - Fluence in Neutrons } / \mathrm{cm}^{2}\end{array}$

\subsection{SAFETY LIMITS (SL)}

Safety Limits are values placed on process variables which can impact the condition of the reactor fuel. The purpose for limiting these variables is to ensure that the integrity of ESSSC barriers designed to prevent and/or mitigate the uncontrolled release of radioactive materials is not degraded unless the process variable is exceeded.

The SL is based on conservative calculations of downwind doses which may result from an uncontrolled release (assumed to be the unmitigated release) of fission products. A bounding value is employed on reactor performance to ensure that the fuel and cladding are not degraded to a point of failure as a result of an event that produces fuel element temperatures higher than maximum routine operations.

In the context of preventing or controlling the release of radioactive materials, accident calculations (SAR, Chapter 14) show that dose commitments to personnel are low for the assumed DESIGN BASIS ACCIDENT (DBA). If an abnormal event or accident occurs, the major concern is the amount of fission 
products released from the fuel element. The parameters that directly affect the amount of fission products released are the fuel material release fraction and the integrity of the fuel element cladding. If the cladding integrity following onset of the event is degraded, fission products may be released from the fuel element; hence the fuel element cladding is the principal ESSSC barrier preventing the uncontrolled release of fission products. Consistent with the definition, Safety Limits are limits on process variables to ensure the integrity of this barrier. The mechanical integrity of the cladding can be inferred from the fuel material temperature. The two controllable process variables which impact the fuel material temperature are: 1) the steady state power level, and 2) the reactivity inserted into the core during transients.

\section{$1.6 \quad$ LIMITING CONTROL SETTINGS (LCS)}

Limiting Control Settings (LCS) are operational bounding values on process variables that prevent exceeding Safety Limits. For the ACRR, fuel temperature is a safety channel which prevents exceeding the safety limit in all OPERATING MODES. Fuel temperature is an observable and measurable quantity and the LCS identifies the maximum allowable value at which system trip action (SCRAM) is initiated.

In the STEADY STATE MODES, Percent Power is the safety channel which also prevents exceeding the SL for Steady State operations.

In the PULSE MODES, reactivity is the process variable which directly impacts the magnitude of a pulse and therefore the resultant fuel temperature. However, reactivity is not a process variable that can be directly measured and is thereby specified as an LCO rather than an LCS. The LCS values for NV and NVT are directly measurable, and provide a SCRAM function to curtail fuel temperatures attained in excessively large pulses.

\subsection{LIMITING CONDITIONS FOR OPERATION (LCO)}

Limiting Conditions for Operation (LCO) are the lowest functional capability or functional level for safety related systems required for operation of the reactor and support systems. For this reactor, the LCO's identify those variables that can be controlled and/or measured to ensure compliance with the requirements of this document.

\subsection{SURVEILLANCE REQUIREMENTS (SR)}

Surveillance requirements ensure that the specified systems and conditions of operation are satisfied and that the quality of these systems are maintained such that the operation of the facility can be maintained within the limits of this document. 


\subsection{REACTOR STEADY STATE POWER LIMIT}

SL: The maximum EQUILIBRIUM reactor power level shall not result in any element power greater than $32 \mathrm{~kW}$ per fuel element .

APPLICABILITY: STEADY STATE MODES

ACTIONS:

\begin{tabular}{|c|c|c|}
\hline CONDIMON & RESPONSE & CQMPUEXTON TIME \\
\hline \multirow[t]{2}{*}{$\begin{array}{l}\text { Element power greater } \\
\text { than } 32 \mathrm{~kW} / \text { fuel element }\end{array}$} & $\begin{array}{l}\text { Place the reactor in the } \\
\text { SHUTDOWN MODE } \\
\text { AND }\end{array}$ & IMMEDIATELY \\
\hline & $\begin{array}{l}\text { Perform the actions as } \\
\text { specified in the } \\
\text { Administrative Controls } \\
\text { Section } 5.3\end{array}$ & Prior to restart \\
\hline
\end{tabular}

\subsection{REACTOR PULSE OPERATION}

SL: The reactivity inserted during a pulse shall not exceed $6.00 \$$.

APPLICABILITY: PULSE MODES

ACTIONS:

\begin{tabular}{|l|l|l|}
\hline CONDITION & RESPONSE & COMP EETION TIME \\
\hline $\begin{array}{l}\text { Reactivity inserted during } \\
\text { a pulse was greater than } \\
6.00 \$\end{array}$ & $\begin{array}{l}\text { Place the reactor in the } \\
\text { SHUTDOWN MODE }\end{array}$ & IMMEDIATELY \\
& AND & \\
\cline { 2 - 3 } & $\begin{array}{l}\text { Perform the actions as } \\
\text { Specified in the } \\
\text { Administrative Controls } \\
\text { Section 5.3 }\end{array}$ & Prior to restart \\
\hline
\end{tabular}




\subsection{LIMITING CONDITIONS FOR OPERATION (LCO) GENERAL APPLICATION}

3.0.1 Compliance with the LCS's and LCO's is required in the specified MODES.

3.0.2 Upon discovery of a failed compliance condition for an LCS or LCO, the Action Response shall be satisfied within the specified completion time. Corrective actions are permitted to be made by the operations staff within the conditions of the LCS and LCO.

3.0.3 Restoration of an LCO prior to the expiration of the specified completion time of the Action statement removes the requirement to complete the Action statements.

3.0.4 Entry into an OPERATION MODE or other specified condition shall not be made unless the conditions for the LCO are met without reliance on the provisions contained in the Action statements.

3.0.5 Equipment removed from service or declared inoperable to comply with Actions may be returned to service under administrative control solely to perform testing required to demonstrate its OPERABILITY or the OPERABILITY of other equipment. This is an exception to $L C O$ 3.0.2 for the system returned to service under administrative control to perform the testing required to demonstrate OPERABILITY.

3.0.6 LCO's 3.2.3, 3.2.4, 3.2.6, and 3.2.9 applicable to PULSE MODE, and associated surveillances related to PULSE MODE, are not required when the PULSE MODE is not OPERABLE.

\subsection{SURVEILLANCE REQUIREMENT (SR) GENERAL APPLICATION}

4.0.1 SR's must be met for all equipment /components/ conditions to be considered OPERABLE. SR's shall be satisfied prior to entering applicable OPERATING MODES.

4.0.2 SR's do not have to be performed on inoperable equipment.

4.0.3 Each SR shall be satisfied within the specified time. SR's may be deferred if completion of the SR is precluded by activities in the SHUTDOWN and MAINTENANCE MODES.

4.0.4 SR's are satisfied if the time between completion of the surveillance and the start of performance of the subsequent surveillance is less than the specified frequency.

4.0.5 If a surveillance is not performed within the specified time interval, then any affected system, equipment, or component shall be declared inoperable.

4.0.6 When equipment or a component fails the surveillance test, the action required by the TSR for failing to meet the LCO shall be taken.

4.0.7 SR's (except those specifically required for safety when the reactor is shutdown) may be deferred during extended shutdowns for maintenance or modification activities; however, the SR's shall be completed prior to entering applicable OPERATING MODES.

4.0.8 SR's scheduled to occur during an operating sequence which are difficult to perform because of the operation may be deferred to the end of the sequence. 


\section{3/4.1 LIMITING CONTROL SETTINGS}

\subsubsection{Operation Set Points}

LCS: The PPS Safety Channel SCRAM settings shall not exceed the maximum allowable settings in the applicable modes of operation

APPLICABILITY: As shown in following table:

Maximum Settings for PPS Safety Channels

\begin{tabular}{|c|c|c|c|}
\hline $\begin{array}{l}\text { SAFETY } \\
\text { GHANNEL }\end{array}$ & 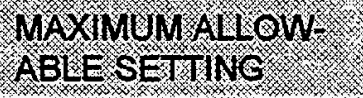 & $\begin{array}{l}\text { RRIP } \\
\text { FENGNON }\end{array}$ & APP LICABLE MOQES \\
\hline Fuel Temperature & $1400^{\circ} \mathrm{C}$ & SCRAM & OPERATING MODES \\
\hline Percent Power & $\begin{array}{l}115 \% \text { (calculated } \\
\text { equivalent of } 25 \mathrm{~kW} \\
\text { for peak fuel element) }\end{array}$ & SCRAM & STEADY STATE MODES \\
\hline NV & $60,000 \mathrm{MW}$ & SCRAM & PULSE MODES \\
\hline NVT & $500 \mathrm{MJ}$ & SCRAM & PULSE MODES \\
\hline
\end{tabular}

ACTIONS:

\begin{tabular}{|c|c|c|}
\hline QONDITON & RESPONSE & GQMPLENION TIME \\
\hline \multirow[t]{2}{*}{$\begin{array}{l}\text { If any Safety Channel } \\
\text { SCRAM setting is greater } \\
\text { than its maximum } \\
\text { allowable setting in the } \\
\text { applicable modes }\end{array}$} & $\begin{array}{l}\text { Place the reactor in the } \\
\text { SHUTDOWN MODE } \\
\text { AND }\end{array}$ & IMMEDIATELY \\
\hline & $\begin{array}{l}\text { Adjust the Safety Channel } \\
\text { SCRAM setting to an } \\
\text { acceptable value }\end{array}$ & $\begin{array}{l}\text { Prior to placing the reactor in } \\
\text { an OPERATING MODE }\end{array}$ \\
\hline \multirow[t]{2}{*}{$\begin{array}{l}\text { If a Safety Channel } \\
\text { SCRAM does not } \\
\text { function when it is } \\
\text { required }\end{array}$} & $\begin{array}{l}\text { Place the reactor in the } \\
\text { SHUTDOWN MODE } \\
\text { AND }\end{array}$ & IMMEDIATELY \\
\hline & $\begin{array}{l}\text { Perform the actions as } \\
\text { specified in the Admini- } \\
\text { strative Controls Section } 5.3\end{array}$ & Prior to restart \\
\hline
\end{tabular}

\subsubsection{Operations Set Point Surveillance Requirements}

\begin{tabular}{|l|l|}
\hline REQUIREMENT & FREQUENCY \\
\hline SR 4.1.1.1 Perform a POWER DETERMINATION & ANNUALLY \\
\cline { 2 - 3 } & $\begin{array}{l}\text { Following a CORE } \\
\text { CONFIGURATION CHANGE } \\
\text { which significantly impacts } \\
\text { power distribution }\end{array}$ \\
\hline
\end{tabular}




\subsubsection{Shutdown Margin}

LCO: The Reactor shall be subcritical with the Safety and Transient Rods fully raised, and the Control Rods fully down.

$\underline{\text { OR }}$

the SHUTDOWN MARGIN verified greater than 25 cents with respect to a cold, xenon free reactor condition with the most reactive rod out.

APPLICABILITY: All Modes.

ACTIONS:

\begin{tabular}{|c|c|c|}
\hline QONDITION & RESPONSE & COMPLETIONTME \\
\hline \multirow{3}{*}{$\begin{array}{l}\text { The reactor achieves } \\
\text { criticality while raising the } \\
\text { Safety and Transient } \\
\text { Rods } \\
\text { OR } \\
\text { The SHUTDOWN } \\
\text { MARGIN is less than } 25 \\
\text { cents }\end{array}$} & $\begin{array}{l}\text { Place the reactor in the } \\
\text { SHUTDOWN MODE }\end{array}$ & IMMEDIATELY \\
\hline & AND & \\
\hline & $\begin{array}{l}\text { Verify that the SHUTDOWN } \\
\text { MARGIN is greater than } 25 \\
\text { cents when the reactor is } \\
\text { cold, xenon free and the } \\
\text { most reactive rod is in the full } \\
\text { up position. }\end{array}$ & $\begin{array}{l}\text { Prior to restarting the reactor } \\
\text { in any OPERATING MODE }\end{array}$ \\
\hline
\end{tabular}

\subsubsection{Shutdown Margin Surveillance Requirements:}

\begin{tabular}{|c|c|c|}
\hline \multicolumn{2}{|c|}{ REQUIREMEN } & FREQUENEY \\
\hline SR 4.2.1.1 & $\begin{array}{l}\text { Verify the SHUTDOWN MARGIN meets the } \\
\text { LCO }\end{array}$ & $\begin{array}{l}\text { During each critical reactor } \\
\text { operation }\end{array}$ \\
\hline \multirow[t]{3}{*}{ SR 4.2.1.2 } & \multirow[t]{3}{*}{$\begin{array}{l}\text { The SHUTDOWN MARGIN shall be } \\
\text { evaluated to satisfy the LCO }\end{array}$} & $\begin{array}{l}\text { Prior to a CORE } \\
\text { CONFIGURATION CHANGE }\end{array}$ \\
\hline & & $\begin{array}{l}\text { Prior to change in design of } \\
\text { the REGULATING RODS }\end{array}$ \\
\hline & & $\begin{array}{l}\text { Whenever a positive worth } \\
\text { experiment is performed }\end{array}$ \\
\hline
\end{tabular}




\subsubsection{Excess Reactivity and Reactivity Insertion Rate}

LCO: The core EXCESS REACTIVITY shall not exceed $12.00 \$$

AND

The average reactivity insertion rate for the Control Rod Bank shall not exceed $0.20 \$ / \mathrm{sec}$

APPLICABILITY: All OPERATING Modes

ACTIONS:

\begin{tabular}{|l|l|l|}
\hline $\begin{array}{l}\text { EXCESS REACTIVITY } \\
\text { greater than 12.00\$ }\end{array}$ & $\begin{array}{l}\text { Place the reactor in the } \\
\text { SHUTDOWN MODE } \\
\text { AND }\end{array}$ & IMMEDIATELY \\
\cline { 2 - 3 } & $\begin{array}{l}\text { Take action to restore the } \\
\text { EXCESS REACTIVITY to } \\
12.00 \$ \text { or less }\end{array}$ & $\begin{array}{l}\text { Prior to exceeding 1\% of the } \\
\text { maximum operating power }\end{array}$ \\
\hline $\begin{array}{l}\text { Control Rod Bank average } \\
\text { reactivity insertion rate } \\
\text { exceeds 0.20\$/sec }\end{array}$ & $\begin{array}{l}\text { Place the reactor in the } \\
\text { SHUTDOWN MODE } \\
\text { AND }\end{array}$ & IMMEDIATELY \\
\cline { 2 - 3 } & $\begin{array}{l}\text { Take action to reduce the } \\
\text { reactivity insertion rate }\end{array}$ & $\begin{array}{l}\text { Prior to exceeding 1\% of the } \\
\text { maximum operating power }\end{array}$ \\
\hline
\end{tabular}

\subsubsection{Excess Reactivity and Reactivity Insertion Rate Surveillance Requirements:}

\begin{tabular}{|c|c|c|}
\hline REQUMREM & IENT & EREQUENCY \\
\hline \multirow{3}{*}{\multicolumn{2}{|c|}{$\begin{array}{l}\text { SR 4.2.2.1 Verify the EXCESS REACTIVITY less than } \\
12.00 \$\end{array}$}} & $\begin{array}{l}\text { Following a CORE } \\
\text { CONFIGURATION CHANGE }\end{array}$ \\
\hline & & $\begin{array}{l}\text { Following a change in } \\
\text { REGULATING ROD design }\end{array}$ \\
\hline & & $\begin{array}{l}\text { Whenever a positive worth } \\
\text { experiment is performed }\end{array}$ \\
\hline SR 4.2.2.2 & $\begin{array}{l}\text { CALIBRATE an increment of the Control Rod } \\
\text { Bank Worth }\end{array}$ & $\begin{array}{l}\text { Following core changes that } \\
\text { can have a significant affect } \\
\text { on the Control Rod Bank } \\
\text { Worth calibration }\end{array}$ \\
\hline SR 4.2.2.3 & CALIBRATE the Transient Rod Bank Worth & $\begin{array}{l}\text { Following core changes that } \\
\text { can have a significant affect } \\
\text { on the Transient Rod Bank } \\
\text { Worth calibration }\end{array}$ \\
\hline SR 4.2.2.4 & $\begin{array}{l}\text { CALIBRATE increments of the Control Rod } \\
\text { Bank Worth }\end{array}$ & ANNUALLY \\
\hline SR 4.2.2.5 & CALIBRATE the Transient Rod Bank Worth & ANNUALLY \\
\hline SR 4.2.2.6 & $\begin{array}{l}\text { Verify the Control Rod Bank average } \\
\text { reactivity insertion rate. }\end{array}$ & $\begin{array}{l}\text { Whenever the Control Rod } \\
\text { Bank is CALIBRATED }\end{array}$ \\
\hline
\end{tabular}




\subsubsection{Pulse Mode Conditions}

LCO: The specified reactor core conditions shall be satisfied for PULSE MODES

APPLICABILITY: As shown in the following table:

Required Core Conditions for PULSE MODES

\begin{tabular}{|l|l|l|}
\hline $\begin{array}{l}\text { P PRRA MEXER } \\
\text { Element Loading }\end{array}$ & $\begin{array}{l}\text { 200 elements or greater (and } \\
6 \text { fuel-followed control rods) }\end{array}$ & PULSE MODES \\
\hline External Reflection & $\begin{array}{l}\text { Outer core perimeter } \\
\text { reflected by nickel reflector } \\
\text { elements or equivalent }\end{array}$ & PULSE MODES \\
\hline $\begin{array}{l}\text { Internal Reflection } \\
\text { Transient Rod Bank } \\
\text { Reactivity Worth }\end{array}$ & $\begin{array}{l}\text { Inner core hexagonal cavity } \\
\text { reflected by steel-walled } \\
\text { central cavity or equivalent }\end{array}$ & PULSE MODES \\
\hline $\begin{array}{l}\text { Transient Rod Bank } \\
\text { DYNAMIC REACTIVITY } \\
\text { WORTH }\end{array}$ & Not to exceed 4.25\$ & $\begin{array}{l}\text { PULSE MODES (excluding } \\
\text { TRW MODE) }\end{array}$ \\
\hline
\end{tabular}

ACTIONS:

\begin{tabular}{|c|c|c|}
\hline OONOITHON & RESPONSE & COMPLEXION WME \\
\hline $\begin{array}{l}\text { Core does not contain } 200 \\
\text { elements or greater }\end{array}$ & $\begin{array}{l}\text { Place the reactor in the } \\
\text { STEADY STATE MODE }\end{array}$ & IMMEDIATELY \\
\hline $\begin{array}{l}\text { Core not externally } \\
\text { reflected }\end{array}$ & $\begin{array}{l}\text { Place the reactor in the } \\
\text { STEADY STATE MODE }\end{array}$ & IMMEDIATELY \\
\hline $\begin{array}{l}\text { Core not internally } \\
\text { reflected }\end{array}$ & $\begin{array}{l}\text { Place the reactor in the } \\
\text { STEADY STATE MODE }\end{array}$ & IMMEDIATELY \\
\hline \multirow[t]{2}{*}{$\begin{array}{l}\text { Transient Rod Bank } \\
\text { reactivity available for a } \\
\text { pulse is greater than } 3.50 \$\end{array}$} & $\begin{array}{l}\text { Place the reactor in the } \\
\text { STEADY STATE MODE } \\
\text { AND }\end{array}$ & IMMEDIATELY \\
\hline & $\begin{array}{l}\text { Act to restore the Transient } \\
\text { Rod Bank reactivity available } \\
\text { for a pulse to } 3.50 \$ \text { or less }\end{array}$ & $\begin{array}{l}\text { Prior to placing the reactor in } \\
\text { the PULSE MODES } \\
\text { (excluding TRW MODE) }\end{array}$ \\
\hline \multirow[t]{2}{*}{$\begin{array}{l}\text { Transient Rod Bank } \\
\text { DYNAMIC REACTIVITY } \\
\text { WORTH greater than } \\
4.25 \$\end{array}$} & $\begin{array}{l}\text { Place the reactor in the } \\
\text { STEADY STATE MODE } \\
\text { AND }\end{array}$ & IMMEDIATELY \\
\hline & $\begin{array}{l}\text { Act to restore the Transient } \\
\text { Rod Bank DYNAMIC } \\
\text { REACTIVITY WORTH to } \\
4.25 \$ \text { or less }\end{array}$ & $\begin{array}{l}\text { Prior to placing the reactor in } \\
\text { the TRW MODE }\end{array}$ \\
\hline
\end{tabular}




\subsubsection{Pulse Mode Conditions Surveillance Requirements:}

\begin{tabular}{|c|c|c|}
\hline \multicolumn{2}{|c|}{ REQURENENT } & \multirow{2}{*}{$\begin{array}{l}\text { REQUENCY } \\
\text { STARTUP on days of } \\
\text { PULSE MODE operations }\end{array}$} \\
\hline SR 4.2.3.1 & $\begin{array}{l}\text { Verify the Core } \mathrm{UO}_{2}-\mathrm{BeO} \text { Fuel Element } \\
\text { Loading }\end{array}$ & \\
\hline SR 4.2.3.2 & Verify the External Reflection & $\begin{array}{l}\text { STARTUP on days of } \\
\text { PULSE MODE operations }\end{array}$ \\
\hline SR 4.2.3.3 & Verify the Internal Reflection & $\begin{array}{l}\text { STARTUP on days of } \\
\text { PULSE MODE operations }\end{array}$ \\
\hline SR 4.2.3.4 & $\begin{array}{l}\text { Verify the Transient Rod Bank reactivity } \\
\text { available for a pulse }\end{array}$ & $\begin{array}{l}\text { Prior to ejection of the } \\
\text { Transient Rods for a PULSE }\end{array}$ \\
\hline \multirow[t]{3}{*}{ SR 4.2.3.5 } & \multirow[t]{3}{*}{ Verify the Transient Rod Bank worth } & $\begin{array}{l}\text { Following a CORE } \\
\text { CONFIGURATION CHANGE } \\
\text { (if PULSE MODE operations } \\
\text { are to be conducted) }\end{array}$ \\
\hline & & $\begin{array}{l}\text { Following a change in the } \\
\text { design of the Transient Rods } \\
\text { (if PULSE MODE operations } \\
\text { are to be conducted) }\end{array}$ \\
\hline & & $\begin{array}{l}\text { ANNUALLY } \\
\text { (if PULSE operations are to } \\
\text { be conducted) }\end{array}$ \\
\hline \multirow[t]{4}{*}{ SR 4.2.3.6 } & \multirow[t]{4}{*}{$\begin{array}{l}\text { Verify the Transient Rod Bank DYNAMIC } \\
\text { REACTIVITY WORTH }\end{array}$} & $\begin{array}{l}\text { Following a CORE } \\
\text { CONFIGURATION CHANGE } \\
\text { (if TRW operations are to be } \\
\text { conducted) }\end{array}$ \\
\hline & & $\begin{array}{l}\text { Following a change in the } \\
\text { design of the Transient Rods } \\
\text { (if TRW operations are to be } \\
\text { conducted) }\end{array}$ \\
\hline & & $\begin{array}{l}\text { When a change in the static } \\
\text { Transient Rod Bank worth } \\
\text { measurement indicates a } \\
\text { bank worth greater than or } \\
\text { equal to } 4.25 \$ \\
\text { (if TRW operations are to be } \\
\text { conducted) }\end{array}$ \\
\hline & & $\begin{array}{l}\text { ANNUALLY } \\
\text { (if TRW operations are to be } \\
\text { conducted) }\end{array}$ \\
\hline
\end{tabular}




\begin{tabular}{|c|c|c|}
\hline$\wedge 7 \exists \perp \forall I व \exists W W I$ & 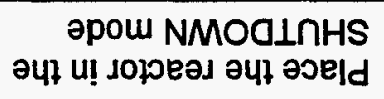 & 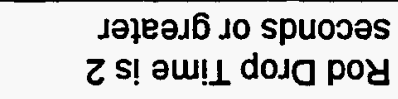 \\
\hline$\wedge 7 \exists \perp \forall I व \exists W W I$ & 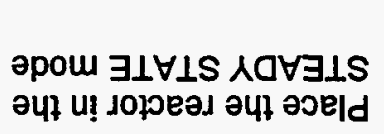 & 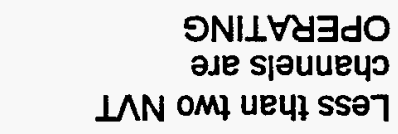 \\
\hline 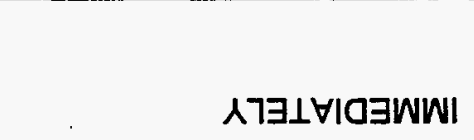 & 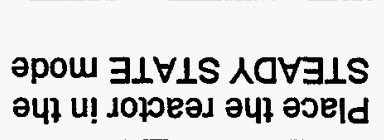 & 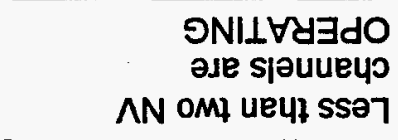 \\
\hline$\lambda 7 \exists \perp \forall I O \exists W W I$ & 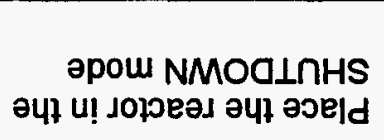 & 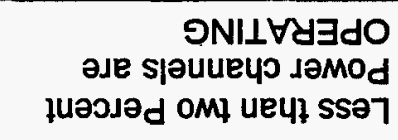 \\
\hline$\lambda\urcorner \exists \perp \forall I a \exists W W I$ & 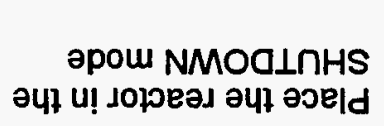 & 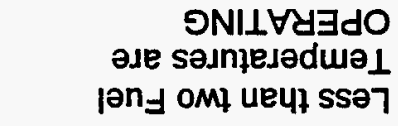 \\
\hline 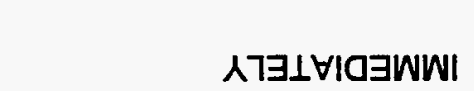 & 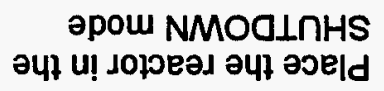 & 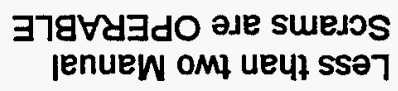 \\
\hline GWII NOHIJano? & asNO.JS J4 & NOIIINO3 \\
\hline
\end{tabular}

\begin{tabular}{|c|c|c|}
\hline 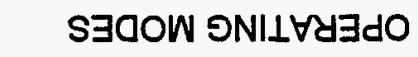 & spuojəs Z บeपł ssə 7 & әu! $\perp$ doدa poy \\
\hline 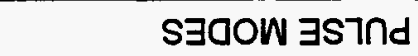 & $($ (әмелр ләd l) 乙 & $L \wedge N$ \\
\hline S JaOW $\exists S 7 n d$ & $($ (амелp səd l) 乙 & $\Lambda N$ \\
\hline S $\exists \square O W \quad \exists \perp \forall \perp S \wedge Q \forall \exists \perp S$ & 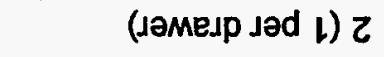 & 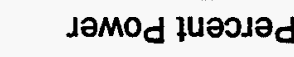 \\
\hline 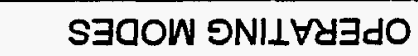 & $($ (әMеJp səd l) Z & 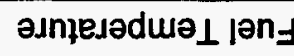 \\
\hline 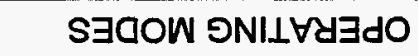 & (ләмелp səd l) Z & mejos Ienuew \\
\hline s J日OW & 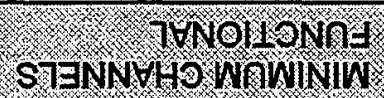 & ANNVHo Sdo \\
\hline
\end{tabular}

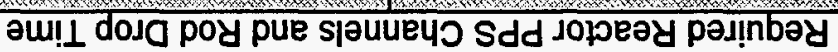

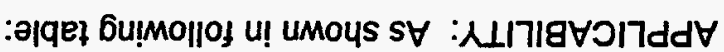

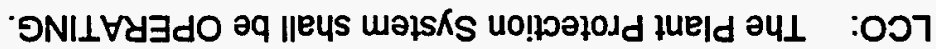




\subsubsection{Plant Protection System Surveillance Requirements:}

\begin{tabular}{|c|c|}
\hline REQUIREMENT & FREQUENCY \\
\hline SR 4.2.4.1 Verify Manual Scram OPERABLE & STARTUP \\
\hline $\begin{array}{c}\text { SR 4.2.4.2 Perform CHANNEL TEST of the Fuel } \\
\text { Temperature (one per PPS drawer) }\end{array}$ & STARTUP \\
\hline $\begin{array}{l}\text { SR 4.2.4.3 Perform CHANNEL CHECK of the Fuel } \\
\text { Temperature (one per PPS drawer) }\end{array}$ & $\begin{array}{l}\text { STARTUP AND DAILY (for } \\
\text { operations extending beyond } \\
\text { a day) }\end{array}$ \\
\hline $\begin{array}{l}\text { SR 4.2.4.4 CALIBRATE the PPS Fuel Temperature } \\
\text { Channels }\end{array}$ & ANNUALLY \\
\hline $\begin{array}{l}\text { SR 4.2.4.5 Perform CHANNEL TEST of the Percent } \\
\text { Power (one per PPS drawer) }\end{array}$ & STARTUP \\
\hline $\begin{array}{l}\text { SR 4.2.4.6 Perform CHANNEL CHECK of the Percent } \\
\text { Power (one per PPS drawer) }\end{array}$ & $\begin{array}{l}\text { STARTUP AND DAILY (for } \\
\text { operations extending beyond } \\
\text { a day) }\end{array}$ \\
\hline SR 4.2.4.7 CALIBRATE the PPS Percent Power Channels & ANNUALLY \\
\hline $\begin{array}{l}\text { SR 4.2.4.8 Adjust, as required, the Percent Power } \\
\text { SCRAM set points }\end{array}$ & $\begin{array}{l}\text { Following a CORE } \\
\text { CONFIGURATION CHANGE } \\
\text { which significantly impacts } \\
\text { power distribution }\end{array}$ \\
\hline $\begin{array}{l}\text { SR 4.2.4.9 Perform CHANNEL TEST of the NV channel } \\
\text { (one per PPS drawer) }\end{array}$ & $\begin{array}{l}\text { STARTUP on days of } \\
\text { PULSE MODE operations }\end{array}$ \\
\hline SR 4.2.4.10 CALIBRATE the PPS NV Channels & $\begin{array}{l}\text { ANNUALLY } \\
\text { (if PULSE MODE operations } \\
\text { are to be conducted) }\end{array}$ \\
\hline $\begin{array}{l}\text { SR 4.2.4.11 Adjust, as required, the NV SCRAM set } \\
\text { points }\end{array}$ & $\begin{array}{l}\text { Following a CORE } \\
\text { CONFIGURATION CHANGE } \\
\text { which significantly impacts } \\
\text { power distribution } \\
\text { (if PULSE MODE operations } \\
\text { are to be conducted) }\end{array}$ \\
\hline $\begin{array}{l}\text { SR 4.2.4.12 Perform CHANNEL TEST of the NVT } \\
\text { channel (one per PPS drawer) }\end{array}$ & $\begin{array}{l}\text { STARTUP on days of } \\
\text { PULSE MODE operations }\end{array}$ \\
\hline SR 4.2.4.13 CALIBRATE the PPS NVT Channels & $\begin{array}{l}\text { ANNUALLY } \\
\text { (if PULSE MODE operations } \\
\text { are to be conducted) }\end{array}$ \\
\hline $\begin{array}{l}\text { SR 4.2.4.14 Adjust, as required, the NVT SCRAM set } \\
\text { points }\end{array}$ & $\begin{array}{l}\text { Following a CORE } \\
\text { CONFIGURATION CHANGE } \\
\text { which significantly impacts } \\
\text { power distribution } \\
\text { (if PULSE MODE operations } \\
\text { are to be conducted) }\end{array}$ \\
\hline SR 4.2.4.15 Verify Rod Drop Time & ANNUALLY \\
\hline
\end{tabular}




\subsubsection{Instrumentation and Control System}

LCO: The Instrumentation and Control System shall be OPERATING.

APPLICABILITY: As shown in following table:

Required Instrumentation and Control System Channels

\begin{tabular}{|c|c|c|}
\hline MSTRUMENT & $\begin{array}{l}\text { WNMMN CHANNELS } \\
\text { FUNGTIONAL. }\end{array}$ & APPLCABLE MOQES \\
\hline Mode Switch & 1 & OPERATING MODES \\
\hline Startup Rate & 1 & STEADY STATE MODE \\
\hline Log Power & 1 & STEADY STATE MODE \\
\hline Linear Power & 1 & STEADY STATE MODE \\
\hline $\begin{array}{l}\text { Control Rod Drive } \\
\text { Position Indicator }\end{array}$ & $\begin{array}{l}1 \text { per each of the } 6 \text { control } \\
\text { rods }\end{array}$ & OPERATING MODES \\
\hline $\begin{array}{l}\text { Transient Rod Drive } \\
\text { Position Indicator }\end{array}$ & $\begin{array}{l}1 \text { per each installed transient } \\
\text { rod }\end{array}$ & OPERATING MODES \\
\hline $\begin{array}{l}\text { Safety Rod Drive Up and } \\
\text { Down Limit Switch }\end{array}$ & $\begin{array}{l}1 \text { up and } 1 \text { down per each } \\
\text { installed safety rod drive }\end{array}$ & OPERATING MODES \\
\hline Rod Down Limit Switch & $\begin{array}{l}1 \text { per each installed } \\
\text { REGULATING ROD }\end{array}$ & OPERATING MODES \\
\hline
\end{tabular}

ACTIONS:

\begin{tabular}{|l|l|l|}
\hline $\begin{array}{l}\text { Mode switch not } \\
\text { OPERABLE }\end{array}$ & $\begin{array}{l}\text { Place the reactor in the } \\
\text { SHUTDOWN MODE }\end{array}$ & IMMEDIATELY \\
\hline $\begin{array}{l}\text { Less than one Startup } \\
\text { Rate channel } \\
\text { OPERATING }\end{array}$ & $\begin{array}{l}\text { Place the reactor in the } \\
\text { SHUTDOWN MODE }\end{array}$ & IMMEDIATELY \\
\hline $\begin{array}{l}\text { Less than one Log Power } \\
\text { channel OPERATING }\end{array}$ & $\begin{array}{l}\text { Place the reactor in the } \\
\text { SHUTDOWN MODE }\end{array}$ & IMMEDIATELY \\
\hline $\begin{array}{l}\text { Less than one Linear } \\
\text { Power channel } \\
\text { OPERATING }\end{array}$ & $\begin{array}{l}\text { Place the reactor in the } \\
\text { SHUTDOWN MODE }\end{array}$ & IMMEDIATELY \\
\hline $\begin{array}{l}\text { Control Rod Drive position } \\
\text { indicator not OPERATING }\end{array}$ & $\begin{array}{l}\text { Place the reactor in the } \\
\text { SHUTDOWN MODE }\end{array}$ & Within 2 hours \\
\hline $\begin{array}{l}\text { Transient Rod Drive } \\
\text { Position indicator not } \\
\text { OPERATING }\end{array}$ & $\begin{array}{l}\text { Place the reactor in the } \\
\text { SHUTDOWN MODE }\end{array}$ & Within 2 hours \\
\hline $\begin{array}{l}\text { Safety Rod Drive Up and } \\
\text { Down limit switches not } \\
\text { OPERATING }\end{array}$ & $\begin{array}{l}\text { Place the reactor in the } \\
\text { SHUTDOWN MODE }\end{array}$ & IMMEDIATELY \\
\hline $\begin{array}{l}\text { Rod Down Limit Switch } \\
\text { not OPERATING }\end{array}$ & $\begin{array}{l}\text { Verify visually that the } \\
\text { armature magnet in contact }\end{array}$ & In 1-hour intervals \\
\hline
\end{tabular}




\subsubsection{Instrumentation and Control System Surveillance Requirements:}

\begin{tabular}{|c|c|}
\hline REQUIREMENT & FREQUENGY \\
\hline $\begin{array}{l}\text { SR 4.2.5.1 Perform a CHANNEL CHECK of the Mode } \\
\text { Switch }\end{array}$ & STARTUP \\
\hline $\begin{array}{l}\text { SR 4.2.5.2 Perform a CHANNEL CHECK of the Reactor } \\
\text { Startup Rate }\end{array}$ & $\begin{array}{l}\text { STARTUP AND DAILY (for } \\
\text { operations extending beyond } \\
\text { a day) }\end{array}$ \\
\hline SR 4.2.5.3 CALIBRATE the Reactor Startup Rate channel & ANNUALLY \\
\hline $\begin{array}{l}\text { SR 4.2.5.4 Perform a CHANNEL CHECK of Log Power } \\
\text { Channel }\end{array}$ & $\begin{array}{l}\text { STARTUP AND DAILY (for } \\
\text { operations extending beyond } \\
\text { a day) }\end{array}$ \\
\hline SR 4.2.5.5 CALIBRATE the Log Power Channel & ANNUALLY \\
\hline $\begin{array}{l}\text { SR 4.2.5.6 Perform a CHANNEL CHECK of the Linear } \\
\text { Power Channel }\end{array}$ & $\begin{array}{l}\text { STARTUP AND DAILY (for } \\
\text { operations extending beyond } \\
\text { a day) }\end{array}$ \\
\hline SR 4.2.5.7 CALIBRATE the Linear Power Channel & ANNUALLY \\
\hline $\begin{array}{l}\text { SR 4.2.5.8 Verify the Control Rod Drive Position } \\
\text { Indicators are OPERATING }\end{array}$ & STARTUP \\
\hline $\begin{array}{l}\text { SR 4.2.5.9 CALIBRATE the Control Rod Drive Position } \\
\text { Indicators }\end{array}$ & ANNUALLY \\
\hline $\begin{array}{l}\text { SR 4.2.5.10 Verify the Transient Rod Drive Position } \\
\text { Indicators are OPERATING }\end{array}$ & STARTUP \\
\hline $\begin{array}{l}\text { SR 4.2.5.11 CALIBRATE the Transient Rod Drive } \\
\text { Position Indicators }\end{array}$ & ANNUALLY \\
\hline $\begin{array}{l}\text { SR 4.2.5.12 Perform a CHANNEL CHECK of the Safety } \\
\text { Rod Drive Limit Switches }\end{array}$ & STARTUP \\
\hline $\begin{array}{l}\text { SR 4.2.5.13 Perform a CHANNEL CHECK of the Rod } \\
\text { Down Limit Switches }\end{array}$ & STARTUP \\
\hline
\end{tabular}




\subsubsection{Control Interlocks}

LCO: The interlocks as described shall be OPERABLE.

APPLICABILITY: As shown in the following table:

Required Control Interlocks

\begin{tabular}{|c|c|}
\hline WTERLOK & NOQESICONDITLNS FOR APPLICABILITY \\
\hline $\begin{array}{l}\text { Safety Rod Withdraw } \\
\text { Enable }\end{array}$ & $\begin{array}{l}\text { - Safety rod group selected, AND } \\
\text { - STEADY STATE MODES, AND } \\
\text { - All scrams and shutdown reset. }\end{array}$ \\
\hline $\begin{array}{l}\text { Control Rod Withdraw } \\
\text { Enable }\end{array}$ & $\begin{array}{l}\text { - Safety rods full up, AND } \\
\text { - STEADY STATE MODES, AND } \\
\text { - Startup rate is less than } 6 \text { DPM, AND } \\
\text { - Control rod group selected. }\end{array}$ \\
\hline $\begin{array}{l}\text { Transient Rod Withdraw } \\
\text { Enable }\end{array}$ & $\begin{array}{l}\text { - Transient rod group selected, AND } \\
\text { - Safety rods are full up, AND } \\
\text { - STEADY STATE MODES, AND } \\
\text { - Startup rate is less than } 6 \text { DPM. }\end{array}$ \\
\hline Auto Mode Enable & $\begin{array}{l}\text { - Control rod group selected in bank, AND } \\
\text { - No control rod is down, AND } \\
\text { - All safety and transient rods are up, AND } \\
\text { - AUTO MODE selected. }\end{array}$ \\
\hline Pulse Mode Enable & $\begin{array}{l}\text { - Reactor power is less than } 1 \% \text { maximum power, AND } \\
\text { - All safety rods full up, AND } \\
\text { - PULSE MODES (excluding TRW MODE), AND } \\
\text { - All pedestals installed. } \\
\text { (Not required if PULSE MODE is not OPERABLE) }\end{array}$ \\
\hline TRW Mode Enable & $\begin{array}{l}\text { - Rod timer master countdown timer reaches zero, AND } \\
\text { - TRW MODE selected, AND } \\
\text { - Reactor power is less than } 1 \% \text { maximum power, AND } \\
\text { - All safety rods are up. } \\
\text { (Not required if TRW MODE is not OPERABLE) }\end{array}$ \\
\hline
\end{tabular}

ACTIONS:

\begin{tabular}{|l|l|l|}
\hline CONDITION & RESPONSE & OMPLETION \\
\hline $\begin{array}{l}\text { Any Enable activated } \\
\text { when modes/conditions } \\
\text { not satisfied }\end{array}$ & $\begin{array}{l}\text { Place the reactor in the } \\
\text { SHUTDOWN mode }\end{array}$ & IMMEDIATELY \\
\hline $\begin{array}{l}\text { Any Enable not activated } \\
\text { when modes/conditions } \\
\text { satisfied }\end{array}$ & $\begin{array}{l}\text { Evaluate the cause of the } \\
\text { failure } \\
\text { AND }\end{array}$ & Indefinite \\
\cline { 2 - 3 } & Act to correct the failure & $\begin{array}{l}\text { Prior to the next operation } \\
\text { requiring the Enable }\end{array}$ \\
\hline
\end{tabular}




\subsubsection{Control Interlocks Surveillance Requirements:}

\begin{tabular}{|c|c|}
\hline REQUIRENENT & FREQEENCY \\
\hline $\begin{array}{l}\text { SR 4.2.6.1 Perform CHANNEL CHECK of the Safety Rod } \\
\text { Withdraw Enable }\end{array}$ & STARTUP \\
\hline $\begin{array}{l}\text { SR 4.2.6.2 Perform CHANNEL CHECK of the Control } \\
\text { Rod Withdraw Enable }\end{array}$ & STARTUP \\
\hline $\begin{array}{l}\text { SR 4.2.6.3 Perform CHANNEL CHECK of the Transient } \\
\text { Rod Withdraw Enable }\end{array}$ & STARTUP \\
\hline $\begin{array}{l}\text { SR 4.2.6.4 Perform CHANNEL CHECK of the Auto Mode } \\
\text { Enable }\end{array}$ & $\begin{array}{l}\text { Prior to initial entry into mode } \\
\text { for that operation }\end{array}$ \\
\hline $\begin{array}{l}\text { SR 4.2.6.5 Perform CHANNEL CHECK of the Pulse Mode } \\
\text { Enable }\end{array}$ & $\begin{array}{l}\text { STARTUP on days of } \\
\text { PULSE MODE operations }\end{array}$ \\
\hline $\begin{array}{l}\text { SR 4.2.6.6 Perform CHANNEL CHECK of the TRW Mode } \\
\text { Enable }\end{array}$ & $\begin{array}{l}\text { STARTUP on days of } \\
\text { TRW MODE operations }\end{array}$ \\
\hline
\end{tabular}




\subsubsection{Reactor Pool Water}

LCO: The reactor pool water shall satisfy the following:

The pool water resistivity shall be greater than $500 \mathrm{kOhm}-\mathrm{cm}$

AND

The pool water inlet temperature to the core shall be less than $50^{\circ} \mathrm{C}$

APPLICABILITY: All OPERATING Modes.

ACTIONS:

\begin{tabular}{|l|l|l|}
\hline $\begin{array}{l}\text { Reactor Pool water } \\
\text { resistivity is } 500 \mathrm{kOhm}-\mathrm{cm} \\
\text { or less }\end{array}$ & $\begin{array}{l}\text { Place the reactor in the } \\
\text { SHUTDOWN MODE }\end{array}$ & 1 hour \\
\hline $\begin{array}{l}\text { Reactor Core inlet water } \\
\text { temperature is } 50^{\circ} \mathrm{C} \text { or } \\
\text { greater }\end{array}$ & $\begin{array}{l}\text { Reduce power and act to } \\
\text { reduce water temperature } \\
\text { OR } \\
\text { Place the reactor in the } \\
\text { SHUTDOWN MODE }\end{array}$ & IMMEDIATELY \\
\hline
\end{tabular}

\subsubsection{Reactor Pool Water Surveillance Requirements:}

\begin{tabular}{|l|l|}
\hline REOURENIENT & FREQUENCY \\
\hline SR 4.2.7.1 Verify reactor pool water resistivity & STARTUP \\
\hline $\begin{array}{c}\text { SR 4.2.7.2 CALIBRATE reactor pool water resistivity } \\
\text { measuring channel }\end{array}$ & ANNUALLY \\
\hline SR 4.2.7.3 Verify reactor core inlet water temperature & Continuous \\
\hline $\begin{array}{l}\text { SR 4.2.7.4 CALIBRATE reactor pool water temperature } \\
\text { channel }\end{array}$ & ANNUALLY \\
\hline
\end{tabular}




\subsubsection{Reactor Room Exhaust (Confinement) Systems}

LCO: The Exhaust Systems shall satisfy the following:

The High Bay Ventilation Exhaust System shall be OPERATING:

a. in the Filtered Mode

$\underline{O R}$

b. able to shift to Filtered Mode.

AND

The Cavity Purge System shall be OPERABLE whenever an open dry cavity is present in the core region.

\section{APPLICABILITY: All OPERATING Modes}

ACTIONS:

\begin{tabular}{|l|l|l|}
\hline CONIOI ION & RESTONSE & COMPLETION TIME \\
\hline $\begin{array}{l}\text { High Bay Ventilation } \\
\text { Exhaust System not } \\
\text { OPERATING }\end{array}$ & $\begin{array}{l}\text { Place the reactor in the } \\
\text { SHUTDOWN MODE }\end{array}$ & IMMEDIATELY \\
\hline $\begin{array}{l}\text { Stack CAM not } \\
\text { OPERABLE }\end{array}$ & $\begin{array}{l}\text { Shift the High Bay Ventilation } \\
\text { to the Filtered Mode }\end{array}$ & IMMEDIATELY \\
\hline $\begin{array}{l}\text { Cavity Purge System not } \\
\text { OPERABLE when } \\
\text { required }\end{array}$ & $\begin{array}{l}\text { Place the reactor in the } \\
\text { SHUTDOWN MODE }\end{array}$ & IMMEDIATELY \\
\hline
\end{tabular}

\subsubsection{Reactor Room Exhaust (Confinement) Systems Surveillance Requirements:}

\begin{tabular}{|c|c|}
\hline REQ QREMENT & FREQUENGY \\
\hline $\begin{array}{l}\text { SR 4.2.8.1 Verify the OPERABILITY of the High Bay } \\
\text { Ventilation Exhaust system }\end{array}$ & STARTUP \\
\hline $\begin{array}{l}\text { SR 4.2.8.2 Verify the OPERABILITY of the Cavity Purge } \\
\text { system. }\end{array}$ & $\begin{array}{l}\text { STARTUP on days when the } \\
\text { Cavity Purge is required }\end{array}$ \\
\hline $\begin{array}{l}\text { SR 4.2.8.3 Verify High Bay Ventilation Exhaust system } \\
\text { flow rates and filter differential pressures. }\end{array}$ & ANNUALLY \\
\hline $\begin{array}{l}\text { SR 4.2.8.4 Verify Cavity Purge system flow rates and } \\
\text { filter differential pressures. }\end{array}$ & ANNUALLY \\
\hline $\begin{array}{l}\text { SR 4.2.8.5 Perform filter efficiency tests on all HEPA } \\
\text { filters in the High Bay Ventilation Exhaust } \\
\text { System and the Cavity Purge System }\end{array}$ & ANNUALLY \\
\hline SR 4.2.8.6 Replace the Cavity Purge charcoal filters & $\begin{array}{l}5 \text { YEARS (interval not to } \\
\text { exceed } 6 \text { years) }\end{array}$ \\
\hline
\end{tabular}




\subsubsection{Limitation On Experiments}

LCO: The reactivity worth of experiments shall satisfy the following

APPLICABILITY: As shown in following table:

Limitations for Experiments

\begin{tabular}{|c|c|c|}
\hline PARAMETER & MINIMUMMCONDITION & APPLEABLE MOQES \\
\hline \multirow[t]{2}{*}{$\begin{array}{l}\text { Reactivity worth of a not } \\
\text { SECURED EXPERIMENT }\end{array}$} & More positive than $-1.00 \$$ & $\begin{array}{l}\text { All OPERATING MODES if } \\
\text { PULSE MODE LCO's in } \\
\text { Section } 3.2 .3 \text { are not } \\
\text { satisfied }\end{array}$ \\
\hline & More positive than $-4.25 \$$ & PULSE MODES \\
\hline $\begin{array}{l}\text { Combined worth of a } \\
\text { MOVEABLE } \\
\text { EXPERIMENT and the } \\
\text { Transient Rod bank }\end{array}$ & Less than $4.25 \$$. & PULSE MODES \\
\hline
\end{tabular}

ACTIONS:

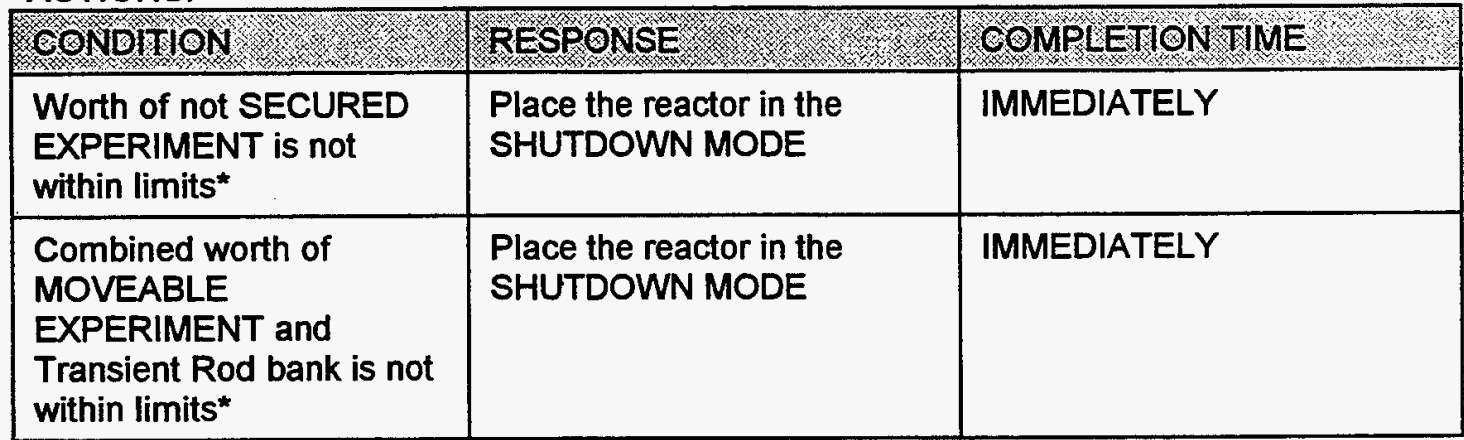

- For the purpose of measuring experiment reactivity worths, critical operations up to $1 \%$ of the maximum operating power are allowed.

\subsubsection{Limitation On Experiments Surveillance Requirements:}

\begin{tabular}{|c|c|}
\hline REQUIREMENT & FREQUENGY \\
\hline $\begin{array}{l}\text { SR 4.2.9.1 Estimate the worth of an experiment prior to } \\
\text { going critical. }\end{array}$ & Each experiment \\
\hline SR 4.2.9.2 Measure the experiment worth. & $\begin{array}{l}\text { For the initial operation in a } \\
\text { unique experiment } \\
\text { configuration }\end{array}$ \\
\hline
\end{tabular}




\subsubsection{Radiation Monitoring Equipment}

LCO: The Radiation Monitoring Equipment shall satisfy the following conditions:

Two out of three of the following RAM's shall be OPERATING:

South Wall RAM

North Wall RAM

Room 51 RAM

AND

Two out of three of the following RAM/CAM's shall be OPERATING:

Pool CAM

Stack CAM

Stack RAM

AND

A RAM or CAM shall be monitoring the Cavity Purge System whenever the Cavity Purge system is required to be operable.

APPLICABILITY: All OPERATING Modes

ACTIONS:

\begin{tabular}{|l|l|l|}
\hline CONOIJION & RESPONSE & COMPLENION TIME \\
\hline $\begin{array}{l}\text { Less than the required } \\
\text { number of RAM/CAM } \\
\text { units OPERATING }\end{array}$ & $\begin{array}{l}\text { Place the reactor in the } \\
\text { SHUTDOWN MODE }\end{array}$ & 1 hour \\
\hline
\end{tabular}

4.2.10 Radiation Monitoring Equipment Surveillance Requirements:

\begin{tabular}{|c|c|}
\hline REQUIREMIEN T & FREQUENCY \\
\hline SR 4.2.10.1 Verify required RAM units are OPERATING & $\begin{array}{l}\text { STARTUP } \\
\text { AND } \\
\text { DAILY (for operations } \\
\text { extending beyond a day) }\end{array}$ \\
\hline SR 4.2.10.2 Verify required CAM units are OPERATING & $\begin{array}{l}\text { STARTUP } \\
\text { AND } \\
\text { DAILY (for operations } \\
\text { extending beyond a day) }\end{array}$ \\
\hline SR 4.2.10.3 CALIBRATE each RAM unit & ANNUALLY \\
\hline SR 4.2.10.4 CALIBRATE each CAM unit & ANNUALLY \\
\hline
\end{tabular}


Administrative Controls are those provisions relating to the organization and management practices applied to the operation of the facility to ensure safe operation.

This section identifies the minimum administrative controls required for the conduct of operations and to ensure compliance with the applicable safety documents, regulatory documents, and other applicable standards as referenced in the safety documents.

Included in this section are discussion for the following:

1. Reactor Operations Organization

2. Responsibilities of the Reactor Operations Organization

3. Reporting TSR Deviations/Violations

4. Procedural Documents

5. Safety Review and Audit Functions

6. Programs

7. Qualification and Training

8. Criticality Safety

9. Experiment Safety

\subsection{Organization}

The administrative line of responsibility is shown in Figure 5-1. Support staff are provided by organizations outside the reactor line organization; these include maintenance, radiation protection, technical support, and ES\&H.

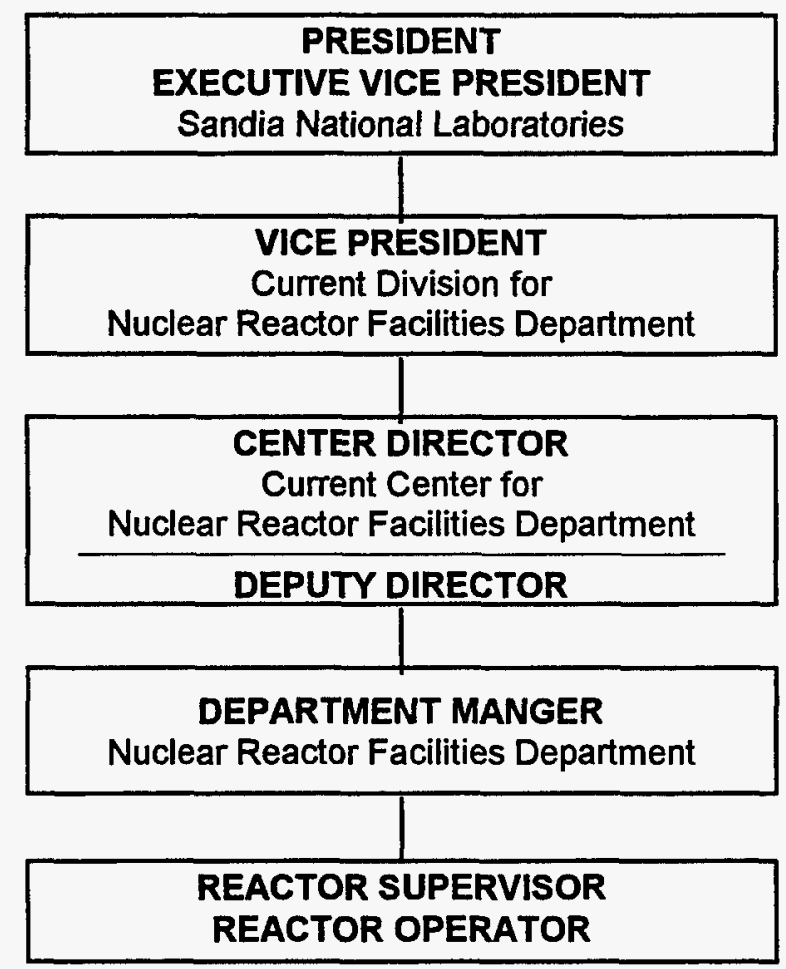

Figure 5-1 Administrative Line of Responsibility 


\subsection{Responsibilities of the Operations Staff}

Overall supervision and management of the operation of the reactor facility is the responsibility of the Manager of the Nuclear Reactor Facilities Department.

The REACTOR SUPERVISOR supervising reactor operations is responsible for the operation of the facility in accordance with the TSR. This includes maintenance of the reactor and reactor systems, setup of experiments, monitoring activities of support groups and ensuring that tasks involving reactor safety systems (ESSSC's) are satisfactorily performed.

The REACTOR OPERATOR performing reactor operations is responsible for performing all reactor console operations associated with the conduct of routine operational modes and setup of experiments. The REACTOR OPERATOR is also responsible for performing regularly scheduled maintenance activities for reactor instrumentation and control systems, and reactor support systems required for the daily operation of the reactor.

The REACTOR SUPERVISOR and REACTOR OPERATOR, conducting reactor operations, are vested with the authority to terminate any reactor operation that in their opinion could result in OPERATING outside the limits of this document or endanger the safety of personnel or equipment.

Minimum operations staff for conduct of critical reactor operations shall be:

One certified REACTOR SUPERVISOR AND one certified REACTOR OPERATOR (one of which must be present in the control room)

AND

the other member of the operating staff within Technical Area 5.

AND

a qualified Health Physicist or qualified Radiological Controls Technician within Technical Area 5.

Minimum operations staff for conduct of PULSE MODE operations shall be:

One certified REACTOR SUPERVISOR AND one certified REACTOR OPERATOR (both present in the control room)

AND

a qualified Health Physicist or qualified Radiological Controls Technician within Technical Area 5.

Minimum operations staff for loading/unloading fuel elements from the core shall be:

One certified REACTOR SUPERVISOR AND one certified REACTOR OPERATOR.

AND

a qualified Health Physicist or qualified Radiological Controls Technician within Technical Area 5

There are two additional categories to accommodate personnel in training. These are:

1 Supervisor-in-Training, and

2. Operator-in-Training.

Personnel in training are authorized to perform work under the direct supervision of a certified REACTOR SUPERVISOR or REACTOR OPERATOR. 


\subsection{Reporting TSR Deviations/Violations}

\subsubsection{Violation of TSR}

Violations of the TSR occur as the result of the following:

1. Exceeding an SL,

2. Failure to perform an Action within the required completion time following:
a. exceeding an LCS, or

b. failing to meet an LCO;

3. Operation when not in compliance with the surveillance requirement consistent with requirements specified in Section 3/4 Operational Limits and Surveillance Requirements, or

4. Failure to comply with an Administrative Control.

\subsubsection{Response to Safety Limit Violations}

1. Place the reactor in a safe condition in accordance with the SL Actions.

2. Notify Line Management and DOE of the violation in accordance with DOE requirements.

3. Prepare an Occurrence Report in accordance with DOE requirements.

4. Perform and document a technical evaluation of the SL violation to determine if any damage may have occurred, and evaluate the capability of the reactor to restart.

5. Obtain DOE approval for restart.

\subsubsection{Response to an LCS or LCO Violation}

1. Place the reactor in a safe condition in which the LCO is not applicable.

2. Notify Line Management and DOE of the violation in accordance with DOE requirements.

3. Prepare an Occurrence Report in accordance with DOE requirements.

\subsubsection{Response to an SR Violation}

1. Perform the Surveillance within 24 hours.

OR

Complete the Actions of the applicable LCO.

2. Notify Line Management and DOE of the violation in accordance with DOE requirements.

3. Prepare an Occurrence Report in accordance with DOE requirements.

\subsubsection{Response to an Administrative Controls (AC) Violation}

1. Notify Line Management and DOE of the violation in accordance with DOE requirements.

2. Prepare an Occurrence Report in accordance with DOE requirements.

3. Perform and document a technical evaluation, if appropriate, of the $A C$ violation to determine if any damage occurred. 


\subsection{Procedural Documents}

Reactor operating procedures shall govern the basic aspects of facility operation for startup, operation, shutdown, and fuel handling for the reactor and reactor facility. This group also includes maintenance procedures for safety related equipment and calibration procedures for safety related equipment and reactivity control elements. Reactor operating procedures shall establish maximum nominal operating power levels preventing challenges to the LCS values, set minimum requirements for number of operable reactivity control rods, and provide appropriate instructions for testing to meet generic LCO 3.0.5.

\subsection{Internal Safety Review and Audit System}

Review and advisement committees shall be established by management. The primary purpose of the committees is to review and advise on the safety of reactor operations. The first tier of review shall be the Annular Core Research Reactor Committee (ACRRC). The ACRRC membership represents reactor operations and directly related disciplines. The ACRRC functions primarily in the role of review relative to technical matters, operation of the reactor, operating procedures, experiment containment qualification, and conduct of experiments. The second tier of review shall be the Sandia Reactor Safety Committee (SRSC). The SRSC membership represents multiple technical disciplines at the management level. The SRSC reviews operations against the requirements of criteria established in the applicable DOE regulations and referenced safety documents. The safety committee structure is collectively referred to as the Sandia Independent Review and Appraisal System (SIRAS). Both committees function under the authority of operating charters issued by line management.

Independent review and audit of facility operations shall be performed by the Audit and Review staff. The Audit and Review staff is constituted by the Sandia Reactor Safety Committee and performs periodic inspections of the reactor operations for compliance with applicable safety documentation.

\subsection{Programs}

Typical programs applicable to operation of the facility include Unreviewed Safety Question, Criticality Safety, Hazardous Waste Handling, Industrial Safety, Fire Protection, and Emergency Preparedness (all are addressed in the SNL ES\&H Manual).

Quality Assurance, Radiation Protection, and the Maintenance Implementation Programs are set forth in separate documents.

\subsection{Qualification and Training - Operations Staff}

A comprehensive training program shall be established for the reactor operators and supervisors. This program is prepared and implemented as required in the DOE-approved Training Implementation Matrix.

\subsection{Criticality Safety}

Criticality safety is addressed in two principal sets of documents, these are:

1. Criticality evaluations for the ACRR facility storage vaults, and

2. SNL ES\&H Manual Supplement, Nuclear Criticality Safety.

These documents outline general guidance based on either documented evaluations or accepted standards to be used for the identification of criticality safety control features. General guidance in the 
form of policy statements, procedures, and operational criteria (such as storage limits) is derived from these documents. Criticality safety measures that require special applications that are outside the boundaries of these documents shall be addressed and established by the ACRR Safety Committee and the Sandia Reactor Safety Committee (see Section 5.5).

Inadvertent reactor criticality shall be prevented under normal reactor configurations by compliance with the LCO for maintaining an adequate shutdown margin. Special precautions shall be taken for MAINTENANCE MODE operations that affect reactivity. If more than two reactivity regulating elements are removed, measures shall be taken to compensate with a sufficient amount of negative reactivity, to prevent an inadvertent criticality.

\subsection{Experiment Safety}

Section 3/4.2.9 identifies limitations on the reactivity changes associated with the conduct of operations involving experiments. Other operational concerns in addition to reactivity changes associated with the conduct of an experiment are limitations on quantities of explosives and hazardous materials.

To ensure adequate containment of fission products, explosives and hazardous materials:

1. SINGLE CONTAINMENT shall:

a) be designed with a minimum pressure safety factor of two.

b) In the case of explosives, be capable of withstanding without rupture, detonation of at least twice the amount of explosives to be irradiated. The containment for explosives may be vented.

2. DOUBLE CONTAINMENT shall be designed such that:

a) each container meets the requirements of SINGLE CONTAINMENT.

b) no single internal event will result in the loss of integrity of both containers.

3. Experiments containing explosive material to be irradiated below the water level of the pool shall meet the following criteria:

a) SINGLE CONTAINMENT shall be required as a minimum.

b) Materials or energy storing systems which could release energy in a sudden explosive manner, and which have sufficient destructive potential, shall be treated as explosives.

4. Experiments containing explosive material to be irradiated above the water level of the pool shall be conducted in a mechanical chamber (container, blast shield, etc.), which has been shown by test or calculation to protect the reactor (specifically the core and reactivity control mechanisms) from the blast effects of twice the amount of explosive material to be irradiated.

5. Experiments containing radioactive and/or fissionable materials shall meet the following criteria:

a) Fission foils in the oxide form (e.g., $\mathrm{PuO}_{2}, \mathrm{UO}_{2}$, and $\mathrm{NpO}_{2}$ ) when contained in a $\mathrm{B}-10$ ball may be exposed to fluences up to $5 E 15 \mathrm{nvt}(>10 \mathrm{keV})$ in any single operation.

b) SINGLE CONTAINMENT shall be used for experiments:

1) if the number of fissions in the material exceeds $5 E 15$ for a single irradiation of the material.

$\underline{\mathrm{OR}}$ 
2) if the combined activity of all fissions and radioactive materials exceeds the activity equivalent to that of $5 \mathrm{E} 15$ fissions.

c) DOUBLE CONTAINMENT shall be used when:

1) the experiment contains isotopes of plutonium,

2) the sum of the fissions in the material exceeds $5 E 18$,

$\underline{O R}$

3) the combined activity of all fissions and radioactive materials exceeds the activity equivalent to that of $5 \mathrm{E} 18$ fissions.

However, SINGLE CONTAINMENT may be used if a safety evaluation shows that the conduct of the experiment, including credible failures, does not produce doses at the Exclusion Area Boundary greater than that specified in the ACRR authorization basis.

6. Experiments containing hazardous materials shall meet the following criteria:

a) A SINGLE CONTAINMENT, as a minimum, shall be required for experiments containing materials classified as severe toxicity hazards

b) SINGLE CONTAINMENT, as a minimum, shall be required for experiments containing highly flammable materials which could be released and ignited.

7. Corrosive materials shall be contained in such a manner as to prevent contact of the material with part of the reactor or reactor components. 
(This Page Intentionally Left Blank) 


\title{
APPENDIX A:
}

\section{BASES for TECHNICAL SAFETY REQUIREMENTS}

\author{
CONTENTS
}

Section Title $\quad \underline{\text { Page }}$

APPENDIX A: BASES FOR TECHNICAL SAFETY REQUIREMENTS ............................................ A1

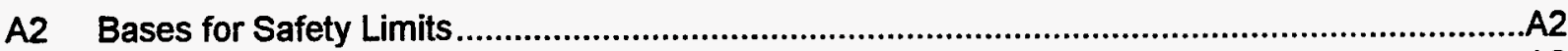

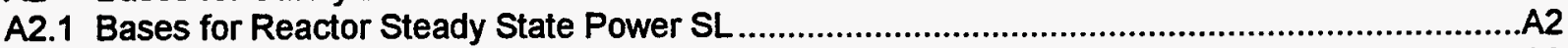

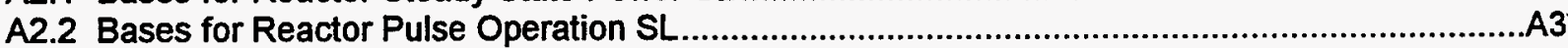

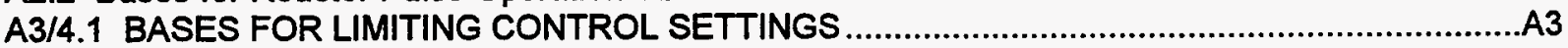

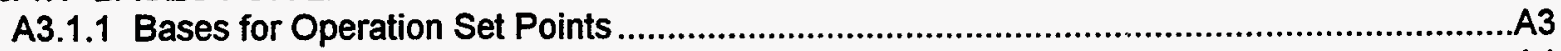

A4.1.1 Bases for Operation Set Point Surveillance ...............................................................

A3/4.2 BASES FOR LIMITING CONDITIONS FOR OPERATION............................................A4

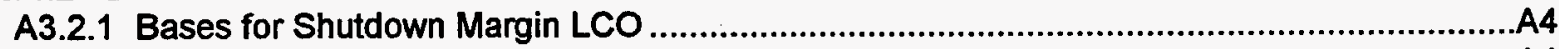

A4.2.1 Bases for Shutdown Margin Surveillance .....................................................................4

A3.2.2 Bases for Excess Reactivity and Reactivity Insertion Rate LCO ...................................A4

A4.2.2 Bases for Excess Reactivity and Reactivity Insertion Rate Surveillance..........................A5

A3.2.3 Bases for Pulse Mode Conditions LCO ....................................................................

A4.2.3 Bases for Pulse Mode Conditions Surveillance ...........................................................

A3.2.4 Bases for Plant Protection System ........................................................................

A4.2.4 Bases for Plant Protection System Surveillance .........................................................A6

A3.2.5 Bases for Instrumentation and Control System .........................................................

A4.2.5 Bases for Instrumentation and Control System Surveillance .....................................A7

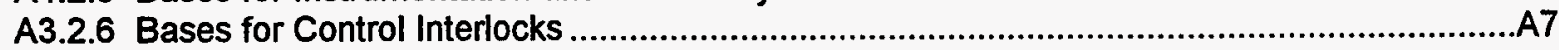

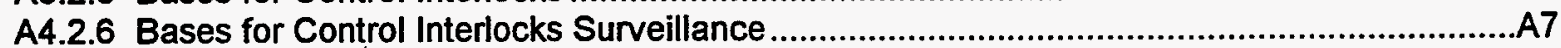

A3.2.7 Bases for Reactor Pool Water..................................................................................

A4.2.7 Bases for Reactor Pool Water Surveillance ..............................................................A7

A3.2.8 Bases for Reactor Room Exhaust (Confinement) Systems.............................................A8

A4.2.8 Bases for Reactor Room Exhaust (Confinement) Systems Surveillance ...........................A8

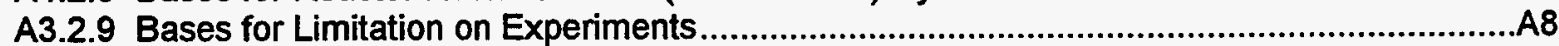

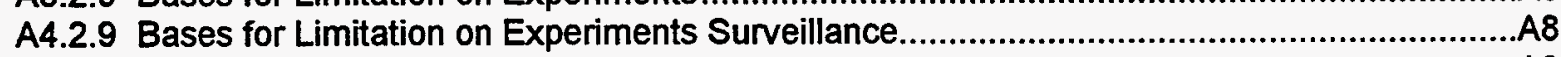

A3.2.10 Bases for Radiation Monitoring Equipment...........................................................

A4.2.10 Bases for Radiation Monitoring Equipment Surveillance ..............................................A9

Figure

Number Title Page

A2.1-1 Steady State SL and LCS Values Relationship to MCHFR for the ACRR A3 
This Appendix provides a summary of the information on which the respective requirements are based and also provides a threshold from which future changes can be evaluated against the original intent or purpose. The information is for the purpose of understanding the basis for the requirements and the reason for the importance of values selected and/or conditions identified for each requirement. Chapters 4 and 14 of the ACRRF Safety Analysis Report contain detailed descriptions of the core design and accident analyses that were used in these bases. Bases section numbers are preceded by a " $A$ " so that they can be easily cross-referenced to corresponding SL, LCS and LCO sections in the TSR.

\section{A2 Bases for Safety Limits}

This section presents a summary discussion of the evaluation for selecting the $S L$ and the bases for the LCS values. The physical barrier which guards against the uncontrolled release of radioactivity from the ACRR is the fuel cladding. Other ESSSC features (such as the reactor pool, ventilation systems, radiation monitors, etc) provide defense-in-depth functions to minimize the consequences of a radioactive release. In the event of a Design Basis Accident, these features also limit the radiation consequences to facility workers and collocated workers. Onset of a DBA involving the failure of the cladding does not challenge the integrity of the other ESSSC features.

The important process variable for assuring the integrity of the fuel element cladding is the fuel element power. The SL's and LCS's are established to assure that the power per element does not attain excessive values.

The two design parameters which are most affected by the fuel element power are the fuel temperature and the cladding mechanical strength. An evaluation of $\mathrm{UO}_{2}-\mathrm{BeO}$ thermophysical properties as a function of fuel temperature is described in Chapter 4 of the ACRRF SAR. The $\mathrm{UO}_{2}$-BeO ceramic starts melting at $2150^{\circ} \mathrm{C}$ equilibrium temperatures for the eutectic. Phenomena governing cladding failure are described in Chapter 4 and 14 of the ACRRF SAR. Excessive cladding temperatures or internal pressures could cause cladding degradation; however, the production of pressure due to outgassing from the fuel is not significant for the $\mathrm{UO}_{2}-\mathrm{BeO}$ fuel composite, hence only degradation of mechanical properties as a function of cladding temperature is of concern. The critical heat flux, as quantified by the Minimum Critical Heat Flux Ratio (MCHFR), is the most important parameter to assure that the cladding temperature does not attain excessive values.

\section{A2.1 Bases for Reactor Steady State Power SL}

The steady state reactor power Safety Limit of $32 \mathrm{~kW} / \mathrm{element}$ is based on the MCHFR for the ACRR core. Figure A2.1-1 shows the relationship between the steady state SL and the MCHFR for the ACRR fuel elements. The figure is a graphical representation of experimentally-determined correlations presented in Table 4.4-2 of the ACRRF SAR. These correlations are shown to be conservative compared to the Bemath correlation. For natural convection cooling as in the ACRR core, the MCHFR is predominantly dependent on inlet water temperature to the core. The core inlet temperature, which can be conservatively measured by the bulk pool temperature, is limited by $L C O 3.2 .7$ to $50^{\circ} \mathrm{C}$. For inlet temperatures up to $50^{\circ} \mathrm{C}$, the SL value of $32 \mathrm{~kW}$ /element has MCHFR values in excess of 1.0 . At 32 $\mathrm{kW} / \mathrm{element}$ and an inlet temperature of $50^{\circ} \mathrm{C}$, the MCHFR is approximately 1.6 which represents the margin of safety to the MCHFR value of 1.0 where cladding failure is expected. This margin of safety accounts for correlation applicability, calculation uncertainties and hot channel discrepancies. As long as peak element power is below $32 \mathrm{~kW}$, the outer clad/coolant interface temperature remains at or below the localized boiling temperature of about $118^{\circ} \mathrm{C}$. The peak fuel temperature for a fuel element operating at $32 \mathrm{~kW}$ is approximately $1800^{\circ} \mathrm{C}$ as shown in Table $14.2-3$ of the ACRRF SAR. 


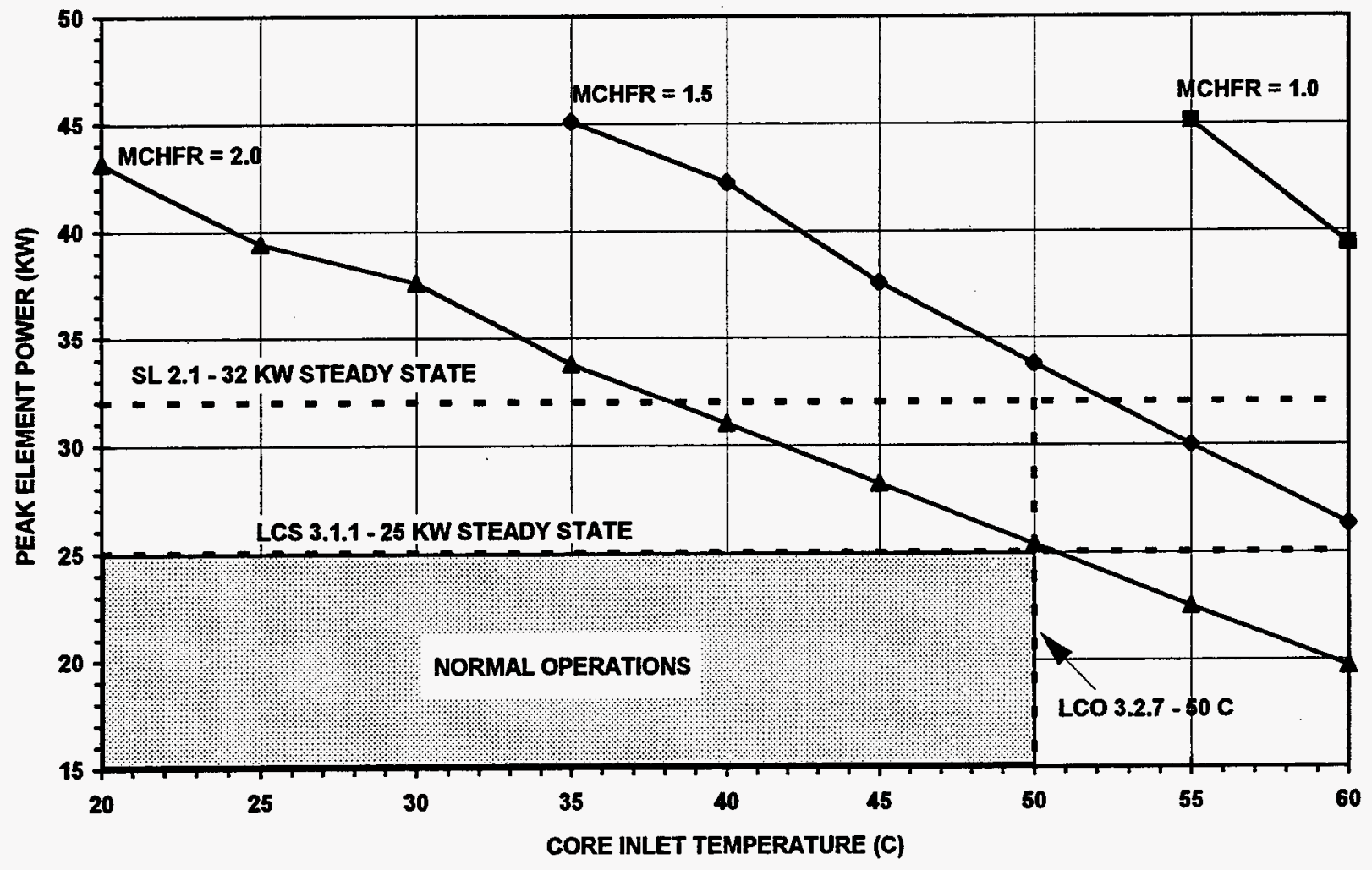

Figure A2.1-1. Steady State.SL and LCS Values Relationship to MCHFR for the ACRR

\section{A2.2 Bases for Reactor Pulse Operation SL}

The purpose of the 6.00 limit on reactivity inserted for a pulse operation is to ensure that the pulse temperature increase is limited such that the peak fuel element is below the start of melt of the fuel material. The peak temperature for a $6.00 \$$ reactivity insertion in $80 \mathrm{msec}$ is $1924^{\circ} \mathrm{C}$ which provides over $200^{\circ} \mathrm{C}$ margin of safety to fuel melt.

\section{A3/4.1 BASES FOR LIMITING CONTROL SETTINGS}

\section{A3.1.1 Bases for Operation Set Points}

The LCS for Fuel Temperature establishes a measured fuel temperature limit which will prevent exceeding the Safety Limit for Steady State Power $\left(32 \mathrm{~kW} /\right.$ /element) and the $1800^{\circ} \mathrm{C}$ peak fuel temperature used to derive the Steady State Power SL. In PULSE MODE operations, the $1400^{\circ} \mathrm{CLCS}$ is compatible with the NV and NVT levels stated herein. At the peak fuel location, a measured temperature of $1400^{\circ} \mathrm{C}$ in the instrumented fuel element is equivalent to a peak fuel temperature of $1500^{\circ} \mathrm{C}$ or less. It is therefore essential that the instrumented fuel elements, which are used to measure temperature, be located at the core locations where the peak fuel temperatures occur or that the ratio of the energy depositions at some other core location to the deposition at the location of the peak fuel temperature be known.

The maximum allowable setting for the Percent Power Safety Channel is $115 \%$ of full power, where $115 \%$ is equivalent to a peak element power of $25 \mathrm{~kW}$ or less. A SCRAM at a power level of $25 \mathrm{~kW}$ for 
the peak fuel element provides protection from exceeding the SL even with a continuous rod withdraw accident in the STEADY STATE Mode. Figure A2.1-1 shows the range of normal operations for the ACRR; including power levels up to $25 \mathrm{~kW} / e$ element and core inlet temperatures up to $50^{\circ} \mathrm{C}$. For this operating range the MCHFR has a value of $\mathbf{2 . 0}$ or greater as illustrated in the figure. The Percent Power Safety Channels obtain power indications by measuring neutron flux usually external to the reactor core.

The LCS limit of $25 \mathrm{~kW} /$ element provides an adequate safety margin to the SL value of $32 \mathrm{~kW} / \mathrm{element}$ to account for PPS actions, transient overshoots, instrument calibration uncertainties and inaccuracies in the fuel element power determination used to determine the core power level trip set point. Procedures will specify the nominal operating power such that adequate operating margin exists to allow for power fluctuation, instrument drift, water density and flow changes, and minor fluctuations in power.

An additional control consideration with high-power, steady-state operations is the oscillations of power as boiling is approached. Due to the natural convection cooling and the small pitch of the ACRR core, power oscillations will start to occur at fuel element power densities over $15 \mathrm{~kW} / \mathrm{element}$ as a function of water temperature. These oscillations increase in magnitude and frequency as fuel element power or water temperature are increased. Reactor controllability can be an issue if the oscillations (peak to peak) exceed 10 percent and the time interval between oscillations becomes less than 10 seconds. To address this situation, operating procedures will restrict operations at these levels as required.

The NV and NVT specifications establish the maximum settings which assure that SCRAM action will occur for pulses with peak fuel temperatures in excess of $1500^{\circ} \mathrm{C}$.

\section{A4.1.1 Bases for Operation Set Point Surveillance}

The SR's for the Operation Set Point LCS's assure that the POWER DETERMINATION used to calibrate Safety Channels are verified on a routine basis (ANNUALLY) and whenever there are changes to the core configuration which can significantly impact the reactor power distributions.

\section{A3/4.2 BASES FOR LIMITING CONDITIONS FOR OPERATION}

\section{A3.2.1 Bases for Shutdown Margin LCO}

The shutdown margin is necessary to assure that the reactor can be made subcritical from any operating condition and remain subcritical after cool down and Xenon decay even if the most reactive regulating rod should stick in the fully withdrawn position.

Verifying that the reactor does not go critical on the Safety and Transient Rod banks is a conservative check for adequate shutdown margin that does not require calculation. A shutdown margin evaluation will show that a margin greater than $0.25 \$$ exists in situations where a positive reactivity effect, such as an experiment, reduces the margin below the Safety and Transient Rod withdrawn criteria.

\section{A4.2.1 Bases for Shutdown Margin Surveillance}

The shutdown margin will be verified during each critical reactor operation to ensure there is always adequate shutdown margin.

\section{A3.2.2 Bases for Excess Reactivity and Reactivity Insertion Rate LCO}

The safety analysis of the continuous bank withdrawal accident is based on a maximum core excess reactivity of $12.00 \$$. 
The ACRRF SAR contains accident analyses for continuous reactivity insertion rates up to $0.20 \$$ per second until the full excess reactivity is inserted. These accidents assume no operator intervention nor automatic SCRAM action. The analyses serves as the basis for the reactivity insertion rate LCO.

Allowing delayed-critical reactor operations up to $1 \%$ of the maximum operating power assures that the excess reactivity can be measured at low powers below $\sim 220$ watts/per element. At this power level, heating of the fuel is anticipated to be negligible or very low.

\section{A4.2.2 Bases for Excess Reactivity and Reactivity Insertion Rate Surveillance}

The excess reactivity will be verified after activities which could affect excess reactivity and prior to performing power operations. These activities consist of: 1) following changes to the core configuration, 2) following a change in regulating rod design, or 3) whenever a positive worth experiment is performed.

A calibration of the Control and Transient Rod Bank Worth for Transient Rod Withdrawal operation, shall be performed following events that can significantly change the worth. A simple check of the Control and Transient Rod banks is performed to verify the bank calibrations have not deviated significantly from the calibration. Accurate bank worth calibrations are necessary for the excess reactivity worth determination.

\section{A3.2.3 Bases for Pulse Mode Conditions LCO}

The pulse mode accident analysis presented in Chapter 14 of the ACRRF SAR assumes three main conditions affecting the power profiles within the core and within a fuel element:

1) the core has a minimum of $200 \mathrm{UO}_{2}-\mathrm{BeO}$ fuel elements (and 6 fuel-followed regulating rods),

2) the core is externally reflected by nickel reflector elements that prevent excessive peaking in the outer fuel rows, and

3) the core is internally decoupled by a steel-walled cavity in the hex region that prevents excessive peaking in the inner fuel rows.

These conditions have been included as LCO's for performing PULSE MODE operations including Transient Rod Withdrawal operations.

The Transient Rod Bank is nominally worth $3.00 \$$ with pedestais installed to limit reactivity available for insertion. Pedestal are used to physically limit the full Transient Rod Bank Worth to acceptable values for PULSE MODE operations other than TRW MODE. For pulses of $6.00 \$$ or less fuel melting is not expected. Thus, $3.50 \$$ is an appropriate limit which takes into account measurement error and provides a safety margin to prevent melting of the fuel.

The full Transient Rod Bank without pedestals is nominally slightly over $4.00 \$$ in worth. For pulses of $6.00 \$$ or less fuel melting is not expected. Thus, $4.25 \$$ is an appropriate limit which takes into account measurement error and provides a safety margin to prevent melting of the fuel.

\section{A4.2.3 Bases for Pulse Mode Conditions Surveillance}

The Transient Rod Bank Worth can be affected by core configuration changes and Transient Rod design changes. A verification of bank worth for both Pulse and TRW operations shall be performed following events that can change the worth.

The DYNAMIC WORTH MEASUREMENT is not performed as routinely as Transient Rod Bank static worth measurements. Changes in the static worth of the rod bank may indicate that dynamic worth changes should be investigated. The dynamic worth measurements are typically lower than static worth 
measurements so determining the dynamic worth measurement when the static worth reaches $4.25 \$$ should preclude a condition where the dynamic worth is excessive.

Annual surveillance of the Transient Bank worth is adequate given the available indications of a change in the worth of the bank during routine reactor operations and the required surveillance if the change is excessive.

The reactivity available for insertion during a pulse is determined prior to the pulse to assure that the transient will be within allowable levels.

\section{A3.2.4 Bases for Plant Protection System}

A manual scram switch is available for the REACTOR OPERATOR to shutdown the reactor without relying on automatic protective functions.

In all OPERATING MODES, the Fuel Temperature Safety Channels provide the capability for an automatic protective function (SCRAM) to prevent operating at excessive levels.

When in STEADY STATE modes, the Percent Power Safety Channel provides additional assurance that the Safety Limit for steady state power will not be exceeded.

When in PULSE Modes, the core and clad are primarily protected by restricting the reactivity available for pulsing the reactor. In addition, each PPS drawer contains secondary safety features which consist of the Fuel Temperature, NV (peak power), and NVT (total energy) Safety Channels. These channels provide additional capability to limit the total energy by reducing the energy in the tail of a pulse. After a pulse, these channels provide redundant and diverse information for determining the magnitude of the pulse.

\section{A4.2.4 Bases for Plant Protection System Surveillance}

The daily tests of the safety channels demonstrate that the required PPS channels are operable. The annual calibrations will permit correction of any long-term drift of the channels. The calibration of SCRAM setpoints assures that after a core configuration change, the safety trip will function at the proper level for changes which can impact that level.

The rod drop time of two seconds is the time used as an initial condition for accidents in the SAR. An actual measurement is only necessary on an annual basis because indications of degradation of scram times are available during routine reactor operations.

\section{A3.2.5 Bases for Instrumentation and Control System}

The Mode Switch is required to control the percent power trips and the rod group control. The mode switch sets the appropriate interlocks for each operating mode.

The Startup Rate channel is one of the channels in the Wide Range Power System. The Startup Rate channel provides operational information on power transients.

The Log Power channel is a wide range measuring channel covering the power range from startup to full power operation in the steady-state mode.

The Linear Power channel is a multi-range measuring channel with the operating range automatically selected. 
The control rod and transient rod position indicators consist of digital readouts which are capable of resolving and displaying each rod's position. The safety rod drive up limit switch and rod down limit switch assure the information is available to determine if the safety rods are fully withdrawn.

\section{A4.2.5 Bases for Instrumentation and Control System Surveillance}

The required tests and checks assure that channels and systems are operable. The annual calibration of the power level channels will permit any long-term drift of the channels to be observed and corrected.

\section{A3.2.6 Bases for Control Interlocks}

The interlocks required for reactor operation assist the operator in satisfying permissive and sequencing conditions. The rod enable logic prevents electromechanical withdrawal of regulating rods in most pulse modes. Regulating rod interlocks assure that normal operating sequences will be performed.

\section{A4.2.6 Bases for Control Interlocks Surveillance}

Interlock operation is verified each time a startup check is performed to ensure proper performance prior to conducting critical reactor operations.

\section{A3.2.7 Bases for Reactor Pool Water}

Pool water resistivity is maintained at or above $500 \mathrm{kOhm}-\mathrm{cm}$ to minimize the likelihood of corrosion of the fuel clad and core support components over the lifetime of the facility.

For the LCS value of $25 \mathrm{~kW}$ per element, a core inlet temperature of $50^{\circ} \mathrm{C}$ or less maintains a MCHFR of greater than 2.0. The core inlet temperature, which can be conservatively measured by the bulk pool temperature, is limited to $50^{\circ} \mathrm{C}$. This water temperature limit is only a concern when operating in the steady state modes. In the event water temperature exceeds $50^{\circ} \mathrm{C}$ the operator takes action to reduce the water temperature such as reducing reactor power and starting the secondary water cooling system. These actions will not cause an instantaneous reduction in water temperature so some time is assumed for these actions to take affect.

\section{A4.2.7 Bases for Reactor Pool Water Surveillance}

Pool water resistivity is verified each time a startup check is performed to ensure the pool water quality is within the acceptable limits. The large volume of water in the pool implies that resistivity changes at a very slow rate.

The pool temperature is continuously monitored to assure that $50^{\circ} \mathrm{C}$ is not exceeded without proper operator action.

Operating experience has shown that the annual drift in the Reactor Pool Water Temperature and Resistivity channel outputs remains within acceptable limits. 


\section{A3.2.8 Bases for Reactor Room Exhaust (Confinement) Systems}

The exhaust air flow rate is greater than the supply flow into the reactor room which ensures that the reactor room pressure relative to the surrounding spaces and the outside environment is negative; hence any air leakage is into the reactor room. The ventilation exhaust system pulls air from the reactor room and when in the filtered mode all reactor room exhaust air goes through HEPA filters prior to release to the environment.

The Cavity Purge system exhausts from experimental cavities and experiments through HEPA and charcoal filters. The primary purpose of the Cavity Purge system is to prevent the build up of Argon 41 in experimental cavities in the core region. The Cavity Purge RAM and CAM monitor the radiation levels going into the system and alert the operator of potential experiment failure.

The GIF Exhaust System which purges air from the GIF cells to environment also contains HEPA filters in line with the air stream. There is no requirement for the GIF Exhaust System to be operating to maintain the confinement function for the reactor room.

\section{A4.2.8 Bases for Reactor Room Exhaust (Confinement) Systems Surveillance}

Operability of the High Bay Ventilation Exhaust system is verified each time a startup check is performed to ensure the system can be shifted to the filtered mode of operation.

Operability of the Cavity Purge system is verified whenever the cavity purge system is required to be operated. This is performed to ensure the system will evacuate radioactive gases from experiment cavities and minimize the possibility of airborne contamination in the high bay.

Operating experience has shown that annual changes in the flow rates and differential pressures for the High Bay Ventilation Exhaust and Cavity Purge systems remain within acceptable limits. In addition, indications available during routine operations would signal significant changes in system performance.

The HEPA filters in the High Bay Exhaust, Cavity Purge and GIF Exhaust systems are efficiency tested on an annual basis. Operating experience has shown this frequency to be adequate to demonstrate proper filter performance.

Charcoal filters in the cavity purge system are used to remove primarily halogens from the air exhausted from a cavity. Operating experience has shown dose rates on the filters to be very low after two years of operation. Extrapolating the expected buildup of radionuclides on the filter media indicates a replacement interval of 5 years is more than adequate to minimize dose rates during operation and maintenance activities.

\section{A3.2.9 Bases for Limitation on Experiments}

Limiting a not SECURED EXPERIMENT to a worth less than $-4.25 \$$ prevents an excursion that is greater than with the transient rods due to unplanned (rapid) motion of an experiment.

Limiting a MOVEABLE EXPERIMENT such that the sum of the transient rod bank reactivity and the experiment reactivity is less than $4.25 \$$ prevents an unplanned excursion greater than that analyzed in the SAR should the transient rod bank and the experiment be simultaneously ejected from the core.

\section{A4.2.9 Bases for Limitation on Experiments Surveillance}

The worth of each experiment is evaluated prior to going critical to ensure there will not be a reactivity excursion beyond what has been analyzed. 
The worth of each unique experiment configuration is measured prior to power operation ( $>1 \%$ full power) with that configuration to ensure there will not be a reactivity excursion beyond what has been analyzed.

\section{A3.2.10 Bases for Radiation Monitoring Equipment}

The pool CAM provides indication of a fuel clad failure. The pool CAM samples the air above the pool surface.

The North Wall, South Wall and Room 51 RAM's provide indication of abnormal general area dose rates in the vicinity of the reactor pool.

The High Bay Ventilation Exhaust Stack monitoring instruments provide indication of the radiation/contamination levels of the air exhausted from the High Bay.

The exhaust through the Cavity Purge system is monitored to provide indication of experiment containment failure.

\section{A4.2.10 Bases for Radiation Monitoring Equipment Surveillance}

The operation of each required RAM unit is verified each time a startup check is performed and daily for extended operations to ensure the RAM will properly indicate a high radiation level and alert the operator to an abnormal condition.

Operability of each CAM unit is verified each time a startup check is performed to ensure the CAM will properly indicate a high airborne contamination level and alert the operator to an abnormal condition.

Operating experience has shown the annual drift in the RAM and CAM unit channel outputs remains within acceptable limits. 
(This Page Intentionally Left Blank) 


\section{DISTRIBUTION}

\section{Sandia National Laboratories/New Mexico}

$\begin{array}{rll}1 & \text { MS-0736 } & \text { J. B. Woodard, 6000 } \\ 1 & \text { MS-0736 } & \text { N. R. Ortiz, 6400 } \\ 1 & \text { MS-1145 } & \begin{array}{l}\text { T. R. Schmidt, 6430 } \\ \text { P. S. Pickard, 6440 }\end{array} \\ 1 & \text { MS-1145 } & \begin{array}{l}\text { J. W. Bryson, 6431 } \\ \text { (for distribution via the TA-V Document Control System) }\end{array} \\ 70 & \text { MS-9018 } & \begin{array}{l}\text { Central Technical Files, 8940-2 } \\ 1\end{array} \\ 2 & \text { MS-0399 } & \begin{array}{l}\text { Technical Library, 4916 } \\ \text { Review \& Approval Desk, 12690 } \\ \text { (for DOE/OSTI) }\end{array}\end{array}$




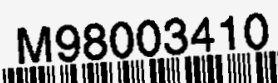

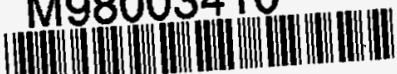

Report Number (14) SAND--98-0051

Publ. Date (11)

Sponsor Code (18)

199801

UC Category (19)

$\frac{D O E / N E, X F}{U C-520, D O E / E R}$

